HETEROCYCLES, Vol. , No. , , pp. -. (C) The Japan Institute of Heterocyclic Chemistry

Received, , Accepted, , Published online, . COM-06- (Please do not delete.)

\title{
ASYMMETRIC 1,3-DIPOLAR CYCLOADDITION REACTIONS OF \\ AZOMETHINE IMINES WITH ACROLEIN CATALYZED BY \\ L-PROLINE AND ITS DERIVATIVES.
}

\author{
Hiroyuki Suga, ${ }^{\dagger *}$ Tadashi Arikawa, ${ }^{\dagger}$ Kennosuke Itoh, ${ }^{\dagger}$ Yukihisa Okumura, ${ }^{\dagger}$ \\ Akikazu Kakehi, ${ }^{\dagger}$ and Motoo Shiro
}

Department of Chemistry and Material Engineering, Faculty of Engineering, Shinshu University, Wakasato, Nagano 380-8553, Japan and Rigaku Corporation, 3-9-12 Matsubaracho, Akishima, Tokyo 196-8666, Japan, E-mail: sugahio@shinshu-u.ac.jp

\begin{abstract}
Dipolar cycloadditions between acrolein and various $N, N^{\prime}$-cyclic azomethine imines in the presence of $\mathbf{L}$-proline and its derivatives as organocatalysts were investigated. Reactions that were catalyzed by (S)-indline-2-carboxylic acid (30 mol\%) in $\mathrm{CHCl}_{3} / \mathrm{MeOH} 97: 3$ (v/v) showed high exo-selectivities (exo/endo 91:9 99:1) and enantioselectivities (75 98\% ee). In contrast, reactions catalyzed by L-proline (30 mol\%) under similar conditions favored the endo-cycloadduct $(83: 27 \sim 99: 1)$ with modest to good enantioselectivities ( $31 \sim 83 \%$ ee). Based on our studies, the diastereoselective mechanism of the L-proline-catalyzed reaction was found to involve the isomerization of the exo- to the endo-cycloadduct in the presence of $\mathbf{L}$-proline.
\end{abstract}

\section{INTRODUCTION}

1,3-Dipolar cycloadditions have served as powerful and effective reactions in the construction of five-membered heterocyclic compounds, commonly found within the fundamental frameworks of numerous biologically important natural products. ${ }^{1,2 c}$ During the past two decades, various catalytic asymmetric 1,3-dipolar cycloadditions that are catalyzed by chiral Lewis acids and organocatalysts have been developed. ${ }^{2} \quad$ For the contribution of such asymmetric dipolar cycloaddition chemistry, we have recently reported on chiral $\mathrm{Ni}$ (II) complexes of binaphthyldiimine (BINIM) as highly effective catalysts for providing high levels of asymmetric induction for the cycloadditions of nitrones, ${ }^{3}$ azomethine imines, ${ }^{4}$ 
nitrile oxides, ${ }^{5}$ and carbonyl ylides. ${ }^{6}$ For the reactions between $N, N$ '-cyclic azomethine imines and 3-acryloyl-2-oxazolidinone, the catalytic effects of the BINIM-Ni(II) complexes were also evident in terms of rate acceleration with high endo- and enantioselectivity of the cycloadducts. ${ }^{4}$ Upon further investigations using ${ }^{1} \mathrm{H}$ NMR, the BINIM-Ni(II) complex was found to be predominantly coordinated to the azomethine imine rather than 3-acryloyl-2-oxazolidinone during the reaction. In contrast to the BINIM-Ni(II)-catalyzed reactions, the use of aminoindanol-derived bis(oxazoline)-Cu(OTf $)_{2}$ as the catalyst resulted in high exo- and enantioselectivities for similar cycloadditions involving $N, N^{\prime}$-cyclic azomethine imines and 2-acryloyl-3-pyrazolidinones. ${ }^{7}$ However, for such chiral Lewis acid-catalyzed reactions, good reactivities with high enantioselectivities were limited to acrylic acid derivatives as the dipolarophiles, presumably due to the relatively basic nature of the $N, N$ '-cyclic azomethine imines. ${ }^{8}$ High levels of asymmetric induction have been reported for the organocatalytic [3+2] cycloadditions of $N, N$ '-cyclic azomethine imines catalyzed by $\alpha, \alpha$-bis-[3,5-di(trifluoromethyl)phenyl]prolinol ${ }^{9}$ (exo-selectivity) and 9-amino-9-deoxyepiquinine derivatives ${ }^{10}$ (endo-selectivity). For these reactions, the disubstituted alkenes, which possess an aldehyde or ketone moiety, were effectively activated as the dipolarophiles - specifically, the above organocatalytic cycloadditions involve $\beta$-substituted- $\alpha, \beta$ unsaturated aldehydes and cyclohexenone, respectively. Acrolein, however, remained to be employed as a dipolarophile for these organocatalytic cycloadditions of $N, N^{\prime}$-cyclic azomethine imines. In this paper, we describe the cycloadditions between acrolein and $N, N^{\prime}$-cyclic azomethine imines that are catalyzed by either L-proline to selectively give the corresponding endo-cycloadducts with good enantioselectivity, or by $(S)$-indoline-2-carboxylic acid to give the exo-cycloadducts with extremely high diastereo- and enantioselectivities.

\section{RESULTS AND DISCUSSION}

\section{Cycloadditions of azomethine imines catalyzed by L-proline}

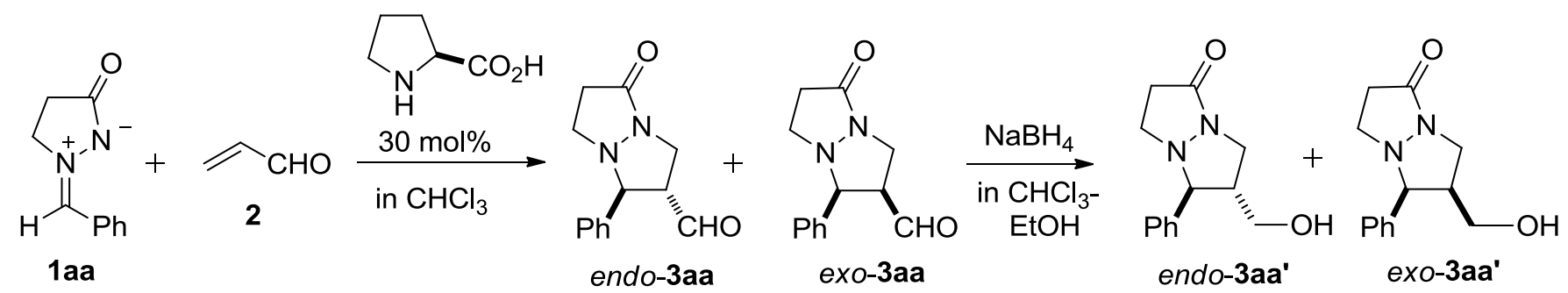

\section{Scheme 1}

Initially, the cycloaddition between azomethine imine 1aa and acrolein (2) was carried out in the presence 
Table 1. L-proline-catalyzed cycloaddition reaction of azomethine imine $\mathbf{1}$ aa with acrolein $(\mathbf{2})^{\mathrm{a}}$

\begin{tabular}{|c|c|c|c|c|c|c|c|}
\hline Entry & $\begin{array}{l}\text { Purification of } \\
\mathrm{CHCl}_{3}{ }^{\mathrm{b}}\end{array}$ & Additive $(\%, v / v)^{\mathrm{c}}$ & Time (h) & Yield $(\%)^{d}$ & endo/exo ${ }^{\mathrm{e}}$ & $\begin{array}{l}\quad \% \mathrm{ee}^{\mathrm{f}} \\
\text { endo }\end{array}$ & exo \\
\hline 1 & No & None & 17 & 93 & $88: 12$ & 78 & 74 \\
\hline 2 & Yes & None & 5 & 66 & 57: 43 & 48 & 58 \\
\hline 3 & Yes & EtOH $(0.1)$ & 17 & 90 & $80: 20$ & 73 & 64 \\
\hline 4 & Yes & $\mathrm{EtOH}(1.0)$ & 20 & 94 & $86: 14$ & 75 & 69 \\
\hline 5 & Yes & $i-\mathrm{PrOH}(1.0)$ & 21 & 53 & $85: 15$ & 76 & 74 \\
\hline 6 & Yes & $\mathrm{MeOH}(0.1)$ & 15 & 81 & $76: 24$ & 73 & 68 \\
\hline 7 & Yes & $\mathrm{MeOH}(0.5)$ & 28 & 84 & $92: 8$ & 73 & 68 \\
\hline 8 & Yes & $\mathrm{MeOH}(1.0)$ & 19 & 85 & $91: 9$ & 77 & ND \\
\hline 9 & Yes & $\mathrm{MeOH}(2.0)$ & 28 & 93 & $95: 5$ & 79 & 77 \\
\hline 10 & Yes & $\mathrm{MeOH}(3.0)$ & 24 & 87 & $94: 6$ & 83 & 84 \\
\hline 11 & Yes & $\mathrm{MeOH}(4.0)$ & 24 & 83 & $89: 11$ & 83 & 88 \\
\hline 12 & Yes & $\mathrm{MeOH}(5.0)$ & 19 & 86 & $78: 22$ & 76 & 84 \\
\hline $13^{\mathrm{g}}$ & Yes & $\mathrm{MeOH}(3.0)$ & 34 & 90 & $73: 27$ & 79 & 88 \\
\hline
\end{tabular}

a The reaction was carried out in $\mathrm{CHCl}_{3}$ in the presence of $\mathbf{L}$-proline $(30 \mathrm{~mol} \%)$ at $25{ }^{\circ} \mathrm{C}$. ${ }^{\mathrm{b}}$ No: commercial grade $\mathrm{CHCl}_{3}$ (stabilized with $\mathrm{EtOH}, 0.3 \sim 1.0 \%$, v/v; Kanto Kagaku) was used without further purifications, Yes: $\mathrm{CHCl}_{3}$ purified by drying with $\mathrm{CaCl}_{2}$ then distilled over $\mathrm{P}_{2} \mathrm{O}_{5}$. ${ }^{\mathrm{c}}$ Percent values $(\mathrm{v} / \mathrm{v})$ are based on the volume of $\mathrm{CHCl}_{3}$. ${ }^{\mathrm{d}}$ The yield of the corresponding alcohols after reduction with $\mathrm{NaBH}_{4}$. ${ }^{\mathrm{e}}$ Determined using ${ }^{1} \mathrm{H}$ NMR analysis. ${ }^{\mathrm{f}}$ Determined using chiral HPLC (Daicel Chiralpak AD-H) analysis after conversion to the corresponding alcohol via $\mathrm{NaBH}_{4}$ reduction. g $10 \mathrm{~mol} \%$ of $\mathbf{L}$-proline was used.

of L-proline (30 mol\%) as the catalyst (Scheme 1, Table 1). Although the reaction in $\mathrm{CH}_{2} \mathrm{Cl}_{2}$ was unsuccessful, ${ }^{11}$ presumably due to the insolubility of $\mathbf{L}$-proline, the reaction in $\mathrm{CHCl}_{3}$ (commercial grade) at $25{ }^{\circ} \mathrm{C}$ for $17 \mathrm{~h}$ gave the cycloadducts in high yield with an endo/exo ratio of 88:12 (entry 1 ). ${ }^{12}$ The cycloadducts were isolated, after reduction with $\mathrm{NaBH}_{4}$, as the corresponding alcohols. Enantiomeric excesses of the endo- (78\% ee) and exo-cycloadducts (74\% ee) were determined using HPLC analysis of the corresponding alcohols. Interestingly, under similar conditions, the use of purified $\mathrm{CHCl}_{3}$ (dried over $\mathrm{CaCl}_{2}$, followed by distillation over $\mathrm{P}_{2} \mathrm{O}_{5}$ ) resulted in a lower yield with decreased diastereo- and enantioselectivity (entry 2). Because commercial grade $\mathrm{CHCl}_{3}$ contains $0.3 \sim 1.0 \%(\mathrm{v} / \mathrm{v}) \mathrm{EtOH}$ as a 
stabilizer, we decided to examine the inclusion of alcohols such as $\mathrm{EtOH}, i-\mathrm{PrOH}$, and $\mathrm{MeOH}$ as additives of dried and purified $\mathrm{CHCl}_{3}$. Among the three alcohols (entries 4, 5, and 8), the addition of $\mathrm{MeOH}$ was found to give the highest diastereo- and enantioselectivity of the endo-cycloadduct (entry 8), in which an amount of 3.0\% (v/v) $\mathrm{MeOH}$ gave the optimal diastereo- (endo/exo 94:6) and enantioselectivity ( $83 \%$ ee) (entry 10). Finally, a lower catalyst loading (10 mol\%) resulted in slightly lower diastereo- (endo/exo 73:27) and enantioselectivity (79\% ee) of the endo-cycloadduct (entry 13). Although a precise role of $\mathrm{MeOH}$ is not clear, an addition of $\mathrm{MeOH}$ presumably increases solubility of L-proline and accelerates the formation of an active iminium ion. An amount of the solvent $\left(\mathrm{CHCl}_{3} / \mathrm{MeOH} 97: 3(\mathrm{v} / \mathrm{v}), 42 \mathrm{~mL}\right.$ for $0.5 \mathrm{mmol}$ scale) is also important factor for the reaction rate probably because of solubility of L-proline.

Table 2. L-proline-catalyzed reactions of azomethine imines with acrolein (2) ${ }^{\mathrm{a}}$
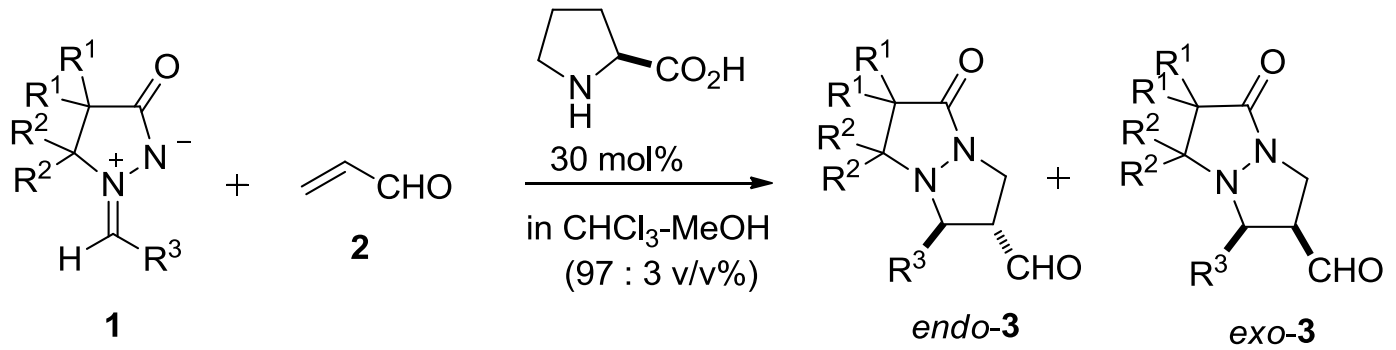

\begin{tabular}{cccccccccc}
\hline Entry & $\mathrm{R}^{1}$ & $\mathrm{R}^{2}$ & $\mathrm{R}^{3}$ & $\mathbf{1}$ & Time $(\mathrm{h})$ & $\mathbf{3}$ & ${\text { Yield }(\%)^{\mathrm{b}}}^{\text {endo/exo }}$ & en ee $^{\mathrm{d}}$ endo \\
\hline 1 & $\mathrm{H}$ & $\mathrm{H}$ & $\mathrm{Ph}$ & $\mathbf{1 a a}$ & 24 & $\mathbf{3 a a}$ & 87 & $94: 6$ & $83(84)^{\mathrm{e}}$ \\
2 & $\mathrm{Me}$ & $\mathrm{H}$ & $\mathrm{Ph}$ & $\mathbf{1 b a}$ & 14 & $\mathbf{3 b a}$ & 89 & $87: 13$ & $78(83)^{\mathrm{e}}$ \\
3 & $\mathrm{H}$ & $\mathrm{Me}$ & $\mathrm{Ph}$ & $\mathbf{1 c a}$ & 39 & $\mathbf{3 c a}$ & 50 & $90: 10$ & $79(69)^{\mathrm{e}}$ \\
4 & $\mathrm{H}$ & $\mathrm{H}$ & $p-\mathrm{ClC}_{6} \mathrm{H}_{4}$ & $\mathbf{1 a b}$ & 24 & $\mathbf{3 a b}$ & 68 & $99: 1$ & 74 \\
5 & $\mathrm{H}$ & $\mathrm{H}$ & $o-\mathrm{ClC}_{6} \mathrm{H}_{4}$ & $\mathbf{1 a f}$ & 48 & $\mathbf{3 a f}$ & 81 & $88: 12$ & 50 \\
6 & $\mathrm{H}$ & $\mathrm{H}$ & $p-\mathrm{MeC}_{6} \mathrm{H}_{4}$ & $\mathbf{1 a g}$ & 24 & $\mathbf{3 a g}$ & 88 & $99: 1$ & 74 \\
7 & $\mathrm{H}$ & $\mathrm{H}$ & $2-\mathrm{Naphthyl}$ & $\mathbf{1 a i}$ & 24 & $\mathbf{3 a i}$ & 85 & $99: 1$ & 82 \\
8 & $\mathrm{H}$ & $\mathrm{H}$ & $\mathrm{Cyclohexyl}$ & $\mathbf{1 a j}$ & 52 & $\mathbf{3 a j}$ & 78 & $>99: 1$ & 31 \\
9 & $\mathrm{H}$ & $\mathrm{H}$ & Isobutyl & $\mathbf{1 a k}$ & 52 & $\mathbf{3 a k}$ & 54 & $83: 27$ & 32 \\
\hline
\end{tabular}

${ }^{a}$ The reactions were carried out in purified $\mathrm{CHCl}_{3} / \mathrm{MeOH} 97: 3(\mathrm{v} / \mathrm{v})$ in the presence of $\mathbf{L}$-proline $(30$ mol\%) at $25{ }^{\circ} \mathrm{C} . \quad{ }^{\mathrm{b}}$ The yield of the corresponding alcohols after reduction with $\mathrm{NaBH}_{4} .{ }^{\mathrm{c}}$ Determined using ${ }^{1} \mathrm{H}$ NMR analysis. $\quad{ }^{\mathrm{d}}$ Determined using chiral HPLC (Daicel Chiralpak AD-H or OD-H) analysis after conversion to the corresponding alcohol via $\mathrm{NaBH}_{4}$ reduction. ${ }^{\mathrm{e}}$ Enantioselectivity of the exo-cycloadduct. 
Next, the cycloadditions were carried out under the optimized conditions using azomethine imines 1 ba and 1ca, which possess dimethyl substituents at their pyrazolidinone ring (Table 2, entries 2 and 3, respectively), to afford the corresponding endo-cycloadducts with relatively good enantioselectivities. The scope of the $\mathrm{R}^{3}$-substituent was investigated using azomethine imines with $p$ - and $o$-substituted phenyl, 2-naphthyl, and alkyl substituents. As shown in entries $4-9$, the reactions exhibited good to high endo-selectivities. Although the imines with $p$-substituted phenyl and 2-naphthyl substituents showed relatively good enantioselectivities, the $o$-chlorophenyl- and alkyl-substituted imines resulted in merely moderate enantioselectivities.

\section{Cycloaddition of azomethine imine 1aa catalyzed by other L-proline derivatives}

In attempts to improve the enantioselectivity, several other L-proline derivatives were evaluated as organocatalysts, as shown in Table 3 (Scheme 1). The use of L-proline derivative 4 (entry 2), which possesses a bulky TBDMSO-substituent at the 4-position of the pyrrolidine ring, failed to improve the enantioselectivity of the endo-cycloadduct. The use of L-proline methyl ester hydrochloride (5) resulted in a reversal of the facial selectivity, albeit with only slight asymmetric induction (entry 3). Although the combination of L-prolinol $\mathbf{6}$ and $p$-nitrobenzoic acid as catalysts resulted in a low-yielding reaction with only slight exo- and enantioselectivity (entry 4), the combination of TMS ether 7 and $p$-nitrobenzoic acid gave the endo-cycloadduct selectively in a high yield (entry 5), thus providing a complimentary enantioselectivity of the endo-cycloadduct to that of L-proline with the opposite facial selectivity. Surprisingly, the reaction catalyzed by $(S)$-indoline-2-carboxylic acid selectively gave the exo-cycloadduct in a high yield with good enantioselectivity (entry 6). Finally, although a longer reaction time was necessary, lowering the reaction temperature to $0{ }^{\circ} \mathrm{C}$ helped improve the exo/endo(91:1) and enantioselectivity (94\% ee) (entry 7).

\section{Cycloadditions of azomethine imines catalyzed by $(S)$-indoline-2-carboxylic acid}

The reaction of azomethine imine 1aa with acrolein (2) in the presence of $10 \mathrm{~mol} \%$ $(S)$-indoline-2-carboxylic acid under similar conditions resulted in decreased yield and exo-selectivity with good enantioselectivity of exo-adduct (Table 4, entry 2). The cycloadditions between acrolein (2) and dimethyl-substituted azomethine imines 1 ba and 1ca proceeded smoothly in the presence of (S)-indoline-2-carboxylic acid (30 mol\%) in $\mathrm{CHCl}_{3} / \mathrm{MeOH} 97: 3(\mathrm{v} / \mathrm{v})$ at $0{ }^{\circ} \mathrm{C}$ to selectively give the corresponding exo-cycloadducts in high yields with high enantioselectivities (entries 3 and 4, respectively). In particular, the highest exo- (>99:1) and enantioselectivy (96\% ee) were obtained using azomethine imine 1ca. Subsequently, dimethyl-substituted azomethine imines $\mathbf{1 c b}-\mathbf{1 c e}$ and $\mathbf{1 c g}-\mathbf{1 c h}$, 
Table 3. Cycloadditions of azomethine imine 1aa with acrolein (2) catalyzed by several organocatalysts $^{\mathrm{a}}$

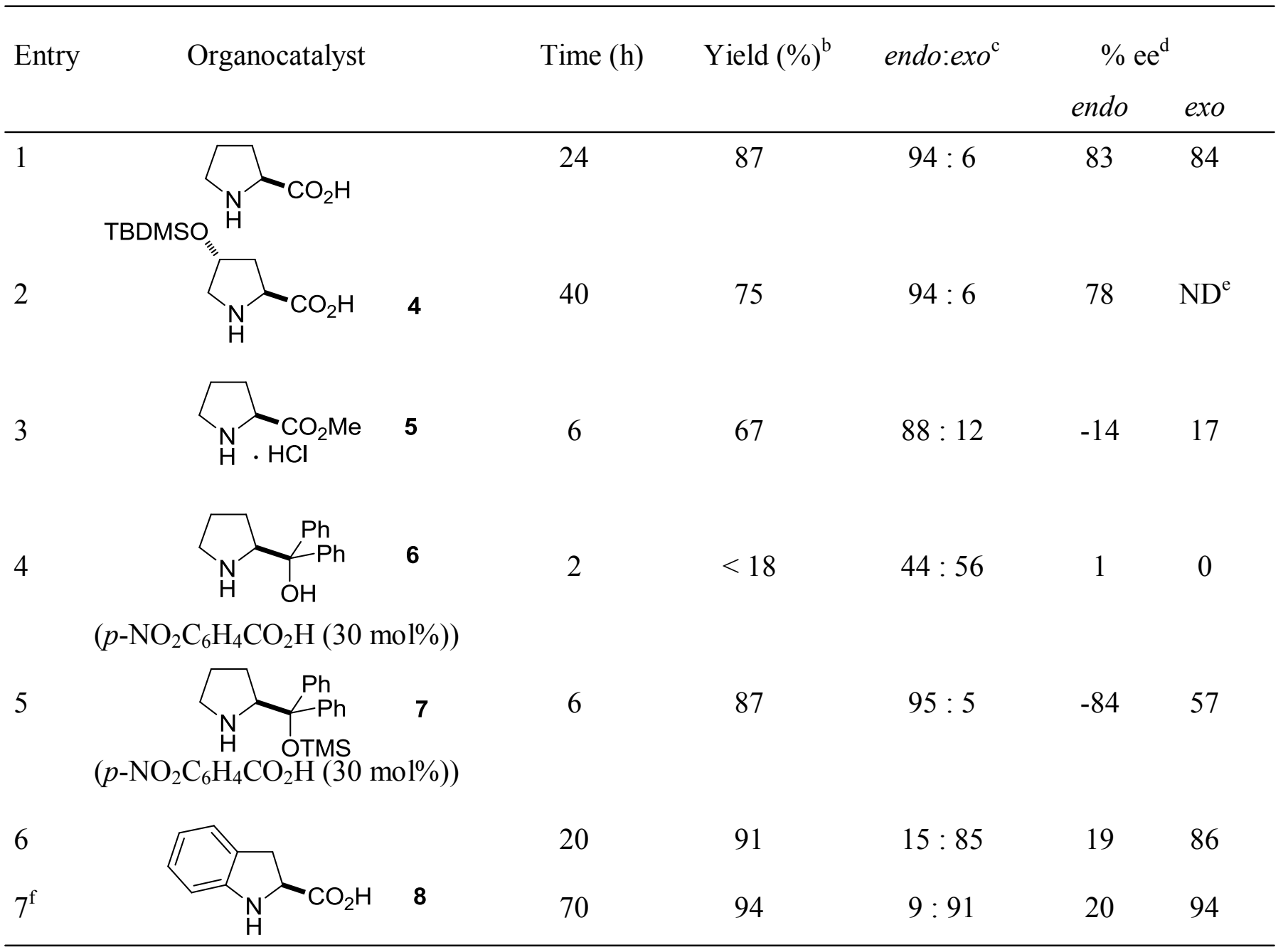

${ }^{\text {a }}$ The reactions were carried out in purified $\mathrm{CHCl}_{3} / \mathrm{MeOH} 97: 3(\mathrm{v} / \mathrm{v})$ in the presence of an organocatalyst (30 mol\%) at $25{ }^{\circ} \mathrm{C}$. ${ }^{\mathrm{b}}$ The yield of the corresponding alcohols after reduction with $\mathrm{NaBH}_{4} .{ }^{\mathrm{c}}$ Determined using ${ }^{1} \mathrm{H}$ NMR analysis. ${ }^{\mathrm{d}}$ Determined using chiral HPLC (Daicel Chiralpak AD-H) analysis after conversion to the corresponding alcohol via $\mathrm{NaBH}_{4}$ reduction. ${ }^{\mathrm{e}}$ Not determined. ${ }^{\mathrm{f}}$ The reaction was carried out at $0{ }^{\circ} \mathrm{C}$.

which possess $p$-substituted phenyl groups as the $\mathrm{R}^{3}$-substituent, were examined under similar conditions. As shown in entries $5-10$, relatively good to excellent enantioselectivies (98 75\% ee) along with extremely high exo-selectivities (> 99:1) were observed, regardless of the electronic character of the $p$-susbstituents. However, in the case of $o$-chlorophenyl derivative $\mathbf{1}$ cf $\left(\mathrm{R}^{1}=\mathrm{H}, \mathrm{R}^{2}=\mathrm{Me}, \mathrm{R}^{3}=\right.$ $o-\mathrm{ClC}_{6} \mathrm{H}_{4}$ ), the reaction did not give cycloadducts under similar conditions. The use of 2-naphthyl derivative 1 ci $\left(\mathrm{R}^{1}=\mathrm{H}, \mathrm{R}^{2}=\mathrm{Me}, \mathrm{R}^{3}=2\right.$-naphthyl) also gave the exo-cycloadduct as the sole product with 
high enantioselectivity (entry 11). Although the reaction of cyclohexyl derivative $\mathbf{1}$ cj $\left(R^{1}=H, R^{2}=M e\right.$, $\mathrm{R}^{3}=$ cyclohecyl) also showed good enantioselectivity with high exo-selectivity, the yield was unsatisfactory (entry 12).

Table 4. (S)-Indoline-2-carboxylic acid-catalyzed cycloadditions of azomethine imines with acrolein $(2)^{\mathrm{a}}$
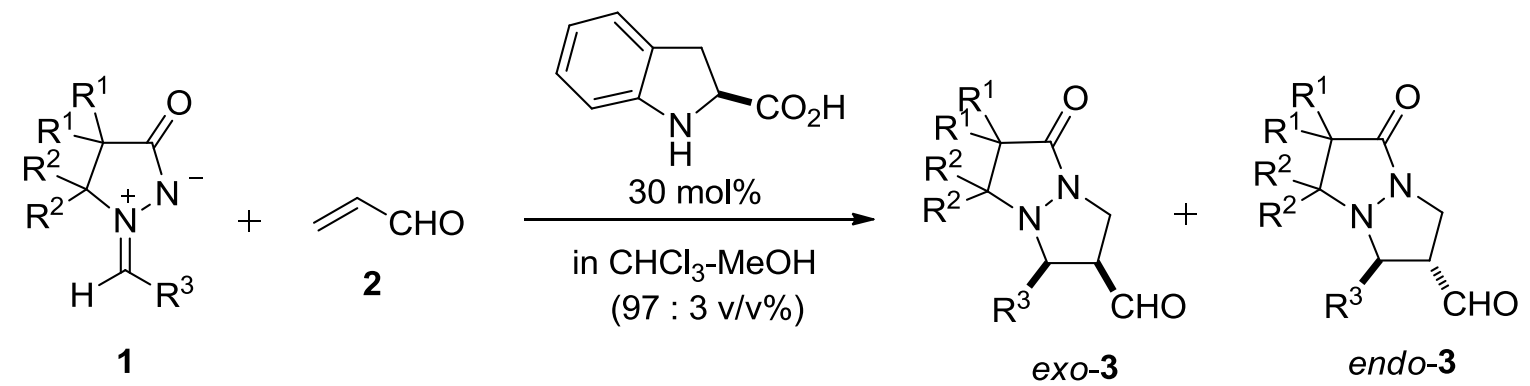

\begin{tabular}{cccccccccc} 
Entry & $\mathrm{R}^{1}$ & $\mathrm{R}^{2}$ & $\mathrm{R}^{3}$ & $\mathbf{1}$ & Time $(\mathrm{h})$ & $\mathbf{3}$ & ${\text { Yield }(\%)^{\mathrm{b}}}$ & exo:endo $^{\mathrm{c}}$ & \% ee $^{\mathrm{d}}$, exo $^{2}$ \\
\hline 1 & $\mathrm{H}$ & $\mathrm{H}$ & $\mathrm{Ph}$ & $\mathbf{1 a a}$ & 70 & $\mathbf{3 a a}$ & 94 & $91: 9$ & $94(20)^{\mathrm{e}}$ \\
$2^{\mathrm{f}}$ & $\mathrm{H}$ & $\mathrm{H}$ & $\mathrm{Ph}$ & $\mathbf{1 a a}$ & 163 & $\mathbf{3 a a}$ & 55 & $88: 12$ & $90(30)^{\mathrm{e}}$ \\
3 & $\mathrm{Me}$ & $\mathrm{H}$ & $\mathrm{Ph}$ & $\mathbf{1 b a}$ & 72 & $\mathbf{3 b a}$ & 95 & $92: 8$ & $93(6)^{\mathrm{e}}$ \\
4 & $\mathrm{H}$ & $\mathrm{Me}$ & $\mathrm{Ph}$ & $\mathbf{1 c a}$ & 36 & $\mathbf{3 c a}$ & 82 & $>99: 1$ & 96 \\
5 & $\mathrm{H}$ & $\mathrm{Me}$ & $p-\mathrm{ClC}_{6} \mathrm{H}_{4}$ & $\mathbf{1 c b}$ & 42 & $\mathbf{3 c b}$ & 72 & $>99: 1$ & 94 \\
6 & $\mathrm{H}$ & $\mathrm{Me}$ & $p-\mathrm{BrC}_{6} \mathrm{H}_{4}$ & $\mathbf{1 c c}$ & 56 & $\mathbf{3 c c}$ & 76 & $>99: 1$ & 93 \\
7 & $\mathrm{H}$ & $\mathrm{Me}$ & $p-\mathrm{CNC}_{6} \mathrm{H}_{4}$ & $\mathbf{1 c d}$ & 60 & $\mathbf{3 c d}$ & 73 & $>99: 1$ & 96 \\
8 & $\mathrm{H}$ & $\mathrm{Me}$ & $p-\mathrm{NO}_{2} \mathrm{C}_{6} \mathrm{H}_{4}$ & $\mathbf{1 c e}$ & 124 & $\mathbf{3 c e}$ & 75 & $>99: 1$ & 75 \\
9 & $\mathrm{H}$ & $\mathrm{Me}$ & $p-\mathrm{MeC}_{6} \mathrm{H}_{4}$ & $\mathbf{1 c g}$ & 42 & $\mathbf{3 c g}$ & 66 & $>99: 1$ & 97 \\
10 & $\mathrm{H}$ & $\mathrm{Me}$ & $p-\mathrm{MeOC}_{6} \mathrm{H}_{4}$ & $\mathbf{1 c h}$ & 56 & $\mathbf{3 c h}$ & 77 & $>99: 1$ & 98 \\
11 & $\mathrm{H}$ & $\mathrm{Me}$ & $2-\mathrm{Naphthyl}$ & $\mathbf{1 c i}$ & 60 & $\mathbf{3 c i}$ & 83 & $>99: 1$ & 95 \\
12 & $\mathrm{H}$ & $\mathrm{Me}$ & $\mathrm{Cyclohexyl}$ & $\mathbf{1 c j}$ & 149 & $\mathbf{3 c j}$ & $<29$ & $>99: 1$ & 88
\end{tabular}

a The reactions were carried out in purified $\mathrm{CHCl}_{3} / \mathrm{MeOH}$ 97:3 (v/v) in the presence of (S)-indoline-2-carboxylic acid $(30 \mathrm{~mol} \%)$ at $0{ }^{\circ} \mathrm{C} . \quad{ }^{\mathrm{b}}$ The yield of the corresponding alcohols after reduction with $\mathrm{NaBH}_{4} . \quad{ }^{\mathrm{c}}$ Determined using ${ }^{1} \mathrm{H}$ NMR analysis. ${ }^{d}$ Determined using chiral HPLC (Daicel Chiralpak AD-H or IA) analysis after conversion to the corresponding alcohol via $\mathrm{NaBH}_{4}$ reduction. $\quad{ }^{\mathrm{e}}$ Enantioselectivity of the endo-cycloadduct. ${ }^{\mathrm{f}}$ The reaction was carried out with $10 \mathrm{~mol} \%$ of the catalyst. 


\section{Isomerization of the exo- to the endo-cycloadduct}

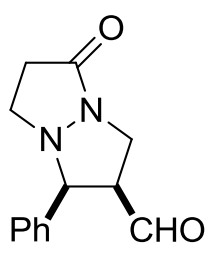

exo-3aa

exo $:$ endo $=92: 8$

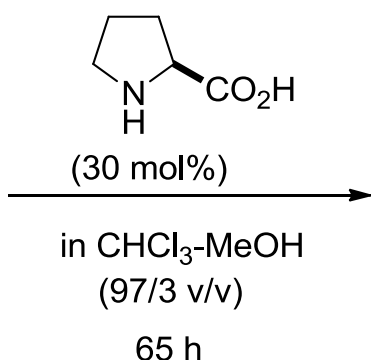

$65 \mathrm{~h}$

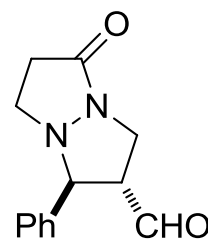

endo-3aa

exo : endo $=6: 94$

\section{Scheme 2}

Table 5. Relationship between reaction time and the endo/exo ratio for L-proline-catalyzed cycloadditions between azomethine imine 1aa and acrolein $(2)^{\mathrm{a}}$

\begin{tabular}{cccccc}
\hline Entry & Time $(\mathrm{h})$ & ${\text { Yield }(\%)^{\mathrm{b}}}^{2}$ & ${\text { endo: } \text { exo }^{\mathrm{c}}}^{\mathrm{N}}$ & \% ee, $^{\mathrm{d}}$ endo & exo \\
\hline 1 & 1 & 27 & $47: 53$ & 82 & 88 \\
2 & 3 & 73 & $60: 40$ & 73 & 82 \\
3 & 6 & 87 & $81: 19$ & 72 & 88 \\
4 & 12 & 92 & $92: 8$ & 79 & 88 \\
5 & 24 & 87 & $94: 6$ & 83 & 84 \\
\hline
\end{tabular}

${ }^{\mathrm{a}}$ The reactions were carried out in purified $\mathrm{CHCl}_{3} / \mathrm{MeOH} 97: 3(\mathrm{v} / \mathrm{v})$ in the presence of L-proline $(30$ mol\%) at $25{ }^{\circ} \mathrm{C} . \quad{ }^{\mathrm{b}}$ The yield of the corresponding alcohols after reduction with $\mathrm{NaBH}_{4} . \quad{ }^{\mathrm{c}}$ Determined using ${ }^{1} \mathrm{H}$ NMR analysis. $\quad{ }^{\mathrm{d}}$ Determined using chiral HPLC (Daicel Chiralpak AD-H or OD-H) analysis after conversion to the corresponding alcohol via $\mathrm{NaBH}_{4}$ reduction.

To gain insight into the reaction mechanisms causing opposite diastereoselectivities exhibited by the L-proline and the $(S)$-indoline-2-carboxylic acid catalyts, an exo-enriched (exo/endo 92:8) mixture of

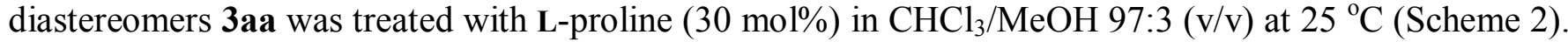
Surprisingly, after stirring for $65 \mathrm{~h}$, the exo/endo ratio indicated an endo-enriched (exo:endo 6:94) mixture, which strongly suggests that the exo-cycloadduct isomerizes to the endo-cycloadduct under our reaction conditions. To further investigate the endo-selectivity of the L-proline-catalyzed reactions, the rate of the endo/exo-isomerization was determined, under a catalyst loading of $30 \mathrm{~mol} \%$ (Table 5, Scheme 1). After a reaction time of $1 \mathrm{~h}$, the cycloadducts were obtained with an endo/exo ratio of 47:53 (27\% yield, 
entry 1). Longer reaction times resulted in higher endo/exo ratios (entries $2-5$ ), ending with an endo/exo ratio of $94: 4$ after $24 \mathrm{~h}$ (87\% yield, entry 5). The enantioselectivities of the endo- and exo-cycloadducts were $83 \%$ ee and $84 \%$ ee, respectively. These results indicate that the exo-cycloadduct isomerizes to the endo-cycloadduct in the presence of $\mathbf{L}$-proline as the catalyst.

\section{Absolute configuration of exo-3cc with reaction mechanism for the asymmetric induction}

To gain insight into the mechanism behind the asymmetric induction, X-ray crystal analysis was carried out using the corresponding alcohol derived from exo-3cc via $\mathrm{NaBH}_{4}$ reduction. For the $(S)$-indoline-2-carboxylic acid-catalyzed reaction, the resulting alcohol obtained via $\mathrm{NaBH}_{4}$ reduction possesses a $(5 S, 6 R)$-configuration (Figure 1). As shown in Scheme 3, the high exo-selectivity can be attributable to the selective formation of a sterically-favorable $Z$-iminium ion that is susceptible to the cycloaddition by the azomethine imine via an exo-approach. The selectivity is further assisted by favorable interactions between the negative charge of the carboxylate ion and the positive charge of the azomethine imine from the upper side of the olefin moiety. The configuration obtained from this facial selectivity (upper side approach) is consistent with that observed by X-ray analysis, as shown in Figure 1.
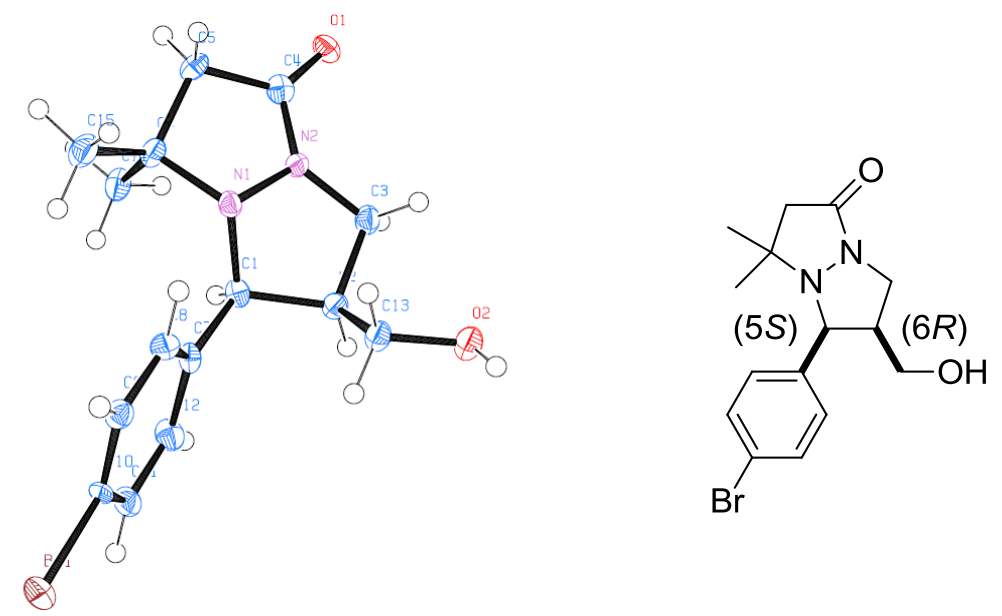

Figure 1. ORTEP drawing of the corresponding alcohol obtained from exo-3cc

On the other hand, for the L-proline-catalyzed reactions, although the initial diastereoselectivity remains unclear, the exo-cycloadduct readily epimerizes at the aldehyde-substituted stereogenic center, under the reaction conditions, to the more thermodynamically stable endo-cycloadduct. The facial selectivity during the asymmetric induction would be similar to that of the $(S)$-indoline-2-carboxylic acid-catalyzed reactions. In contrast to these organocatalysts that possess a carboxylic acid moiety, the 
L-prolininol-derived TMS ether catalyst 7 exhibited the opposite facial selectivity (Table 3, entry 4), which can be attributed to the effective shielding of the upper side by the sterically hindered TMS ether moiety thus blocking the interactions of the positive charge of azomethine imine.
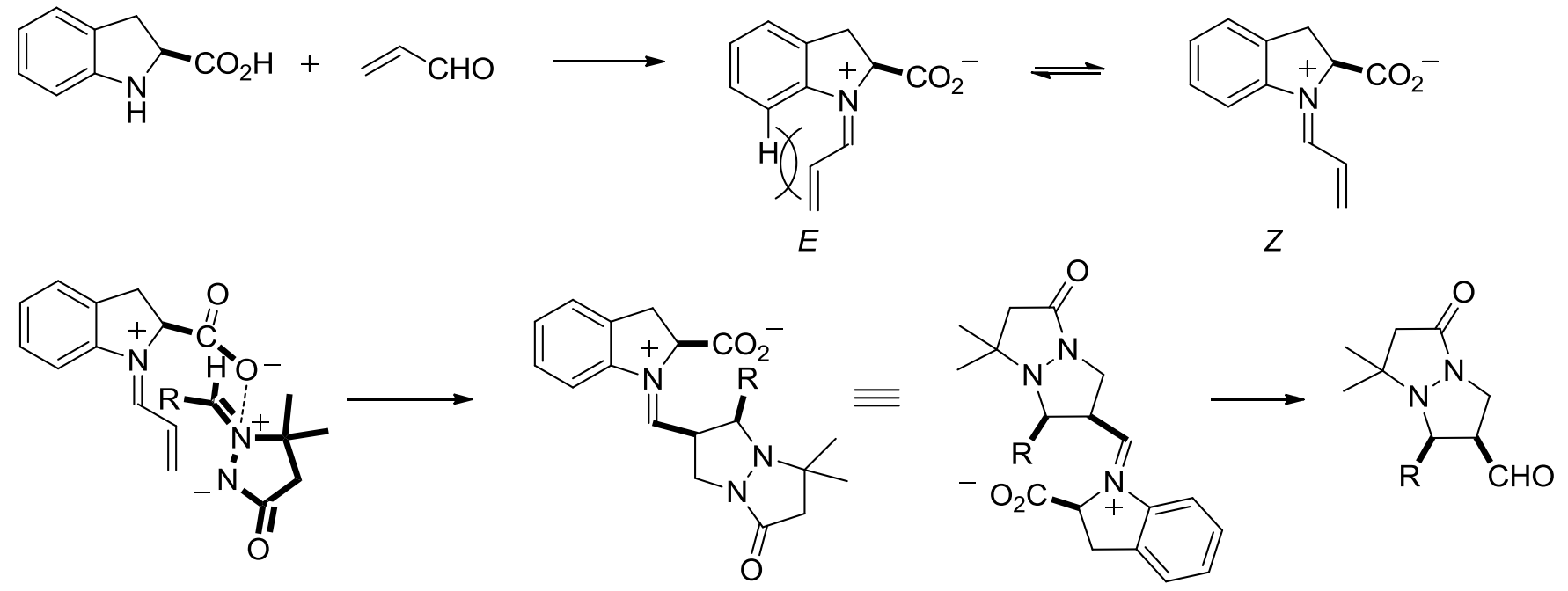

\section{Scheme 3}

\section{CONCLUSION}

We have demonstrated that $(S)$-indoline-2-carboxylic acid $(30 \mathrm{~mol} \%)$ can serve as an efficient organocatalyst for the asymmetric cycloadditions between $N, N^{\prime}$-cyclic azomethine imines and acrolein to afford the corresponding exo-cycloadducts with high diastereo- (91:1 > 99:1) and enantioselectivities (75 $\sim 98 \%$ ee). In contrast, the L-proline catalyst (30 mol\%) afforded the endo-cycloadducts selectively $(83: 27 \sim>99: 1)$ with modest to good enantioselectivities $(31 \sim 83 \%$ ee $)$. The contrasting diastereoselectivites can be explained based on our studies that showed the isomerization of the exo-cycloadduc into the endo-cycloadduct in the presence of L-proline. The solvent system of $\mathrm{CHCl}_{3} / \mathrm{MeOH}$ 97:3 (v/v) was also essential for optimizing the cycloadditions.

\section{EXPERIMENTAL}

Melting points are uncorrected. IR spectra were taken with FT/IR spectrophotometer. ${ }^{1} \mathrm{H}$ NMR spectra were run at $400 \mathrm{MHz}$. Chemical shifts are expressed in parts per million downfield from tetramethylsilane as an internal standard. ${ }^{13} \mathrm{C}$ NMR spectra were recorded at $100 \mathrm{MHz}$ using broadband proton decoupling. Chemical shifts are expressed in parts per million downfield from tetramethylsilane, using the middle resonance of $\mathrm{CDCl}_{3}(77.0 \mathrm{ppm})$ as an internal standard. For preparative column 
chromatography, Wakogel C-300HG was employed. All reactions were carried out under an argon atmosphere in dried glassware. L-Proline, L-proline methyl ester hydrochloride (5), (S)-indoline-2-carboxylic acid (8), and acrolein (2) are commercially available and used without further purification. (4R)-4-( $t$-Butyldimethylsilyloxy)- $L$-proline (4), ${ }^{13} L$-prolinol $6{ }^{14}$ and TMS ether $7^{15}$ were prepared according to the procedure reported previously. Azomethine imines were prepared according to the procedure reported by $\mathrm{Fu}^{16}$ Chloroform was purified by distillation first from $\mathrm{CaCl}_{2}$ and then $\mathrm{P}_{2} \mathrm{O}_{5}$ under argon. Dichloromethane was purified by distillation first from $\mathrm{CaCl}_{2}$ and then $\mathrm{CaH}_{2}$ under argon. Methanol and ethanol were purified by distillation from the corresponding magnesium alkoxide.

General procedure for the asymmetric cycloaddition reaction of azomethine imine with acrolein was exemplified by the reaction of azomethine imine 1ca in the presence of (S)-indoline-2-carboxylic acid.

Azomethine imine $1 \mathrm{ca}(101.1 \mathrm{mg}, 0.50 \mathrm{mmol})$ was added to a solution of acrolein $(66.7 \mu \mathrm{l}, 1.0 \mathrm{mmol})$ and $(S)$-indoline-2-carboxylic acid $(24.5 \mathrm{mg}, 0.15 \mathrm{mmol})$ in $\mathrm{CHCl}_{3}(40.7 \mathrm{~mL})$ and $\mathrm{MeOH}(1.3 \mathrm{~mL})$ at 0 ${ }^{\circ} \mathrm{C}$. After stirring the mixture for $36 \mathrm{~h}$ at the same temperature, a solution of $\mathrm{NaBH}_{4}(75.7 \mathrm{mg}, 2.0$ $\mathrm{mmol})$ in $\mathrm{EtOH}(5.0 \mathrm{~mL})$ was added, and then the stirring was continued for $1 \mathrm{~h}$. The reaction was quenched with saturated $\mathrm{NH}_{4} \mathrm{Cl}$ solution $(5.0 \mathrm{~mL})$ and water $(10.0 \mathrm{~mL})$, and then the mixture was extracted with chloroform $\left(10.0 \mathrm{~mL}\right.$ x 3). The combined extracts were dried over $\mathrm{Na}_{2} \mathrm{SO}_{4}$ and evaporated in vacuo. The residue was chromatographed on silica gel with ethyl acetate and ethyl acetate- $\mathrm{MeOH}(30: 1 \mathrm{v} / \mathrm{v})$ as an eluent to give the corresponding alcohol derived from exo-3ca' (exo : endo $=>99: 1,106.4 \mathrm{mg}, 82 \%$ ). The enantiomeric excess was determined by HPLC analysis (Daicel Chiralpak AD-H, hexane : 2-PrOH $=12: 1 \mathrm{v} / \mathrm{v} \%$, detector: UV $254 \mathrm{~nm}$, flow rate $=0.5 \mathrm{~mL} / \mathrm{min}, 35^{\circ} \mathrm{C}$, $\mathrm{t}_{\text {major }}=47.0 \min ($ exo $), \mathrm{t}_{\text {minor }}=62.4 \min ($ exo $\left.)\right)$.

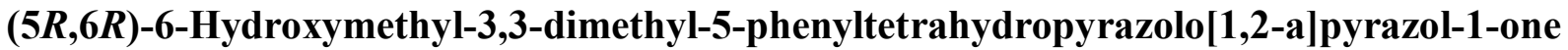

(exo-3ca'): Colorless plates; mp 223-224 ${ }^{\circ} \mathrm{C}\left(\mathrm{MeOH}-\mathrm{Et}_{2} \mathrm{O}\right) ;[\alpha]_{\mathrm{D}}{ }^{26}-60.5^{\circ}$ (c 1.0, $\mathrm{MeOH}$, exo : endo = $>99$ : 1, 96\% ee).; IR (KBr) 3367, 2964, 2926, 2879, 2359, 1678, 1601, 1473, 1432, 1398, 1370, 1296, $1222,1177,1113,1047,970,912,868,758,707,683,625,507 \mathrm{~cm}^{-1} ;{ }^{1} \mathrm{H}$ NMR $\left(\mathrm{CDCl}_{3}\right) \delta=1.06(3 \mathrm{H}, \mathrm{s})$, $1.26(3 \mathrm{H}, \mathrm{s}), 1.60(1 \mathrm{H}, \mathrm{brs}), 2.46(1 \mathrm{H}, \mathrm{d}, J=16.1 \mathrm{~Hz}), 2.68(1 \mathrm{H}, \mathrm{d}, J=16.1 \mathrm{~Hz}), 2.83(1 \mathrm{H}, \mathrm{m}), 3.30(1 \mathrm{H}$, ddd, $J=1.2 \mathrm{~Hz}, 3.9 \mathrm{~Hz}, 11.7 \mathrm{~Hz}), 3.35-3.47(2 \mathrm{H}, \mathrm{m}), 4.00(1 \mathrm{H}, \mathrm{dd}, J=8.5,11.7 \mathrm{~Hz}), 4.17(1 \mathrm{H}, \mathrm{d}, J=7.3$ $\mathrm{Hz}), 7.30-7.45(5 \mathrm{H}, \mathrm{m}) ;{ }^{13} \mathrm{C} \mathrm{NMR}\left(\mathrm{CDCl}_{3}\right) \delta=22.5\left(\mathrm{CH}_{3}\right), 29.1\left(\mathrm{CH}_{3}\right), 43.2\left(\mathrm{CH}_{2}\right), 47.7\left(\mathrm{CH}_{2}\right), 48.2$ $(\mathrm{CH}), 60.2(\mathrm{C}), 62.6\left(\mathrm{CH}_{2}\right), 64.5(\mathrm{CH}), 127.7(\mathrm{CH}), 127.9(\mathrm{CH}), 128.5(\mathrm{CH}), 136.7(\mathrm{C}), 168.7(\mathrm{C})$; Mass 
(EI) $\mathrm{m} / \mathrm{z} 260\left(\mathrm{M}^{+}\right), 201,91,77,56$. Anal. Calcd for $\mathrm{C}_{15} \mathrm{H}_{20} \mathrm{~N}_{2} \mathrm{O}_{2}: \mathrm{C}, 69.20 ; \mathrm{H}, 7.74 ; \mathrm{N}, 10.76 \%$. Found: C, 69.17; H, 7.82; N, 10.72\%.

(5R,6R)-6-Hydroxymethyl-5-phenyltetrahydropyrazolo[1,2-a]pyrazol-1-one (exo-3aa'): Colorless plates; mp 111.5-112.5 ${ }^{\circ} \mathrm{C}$ (benzene); $[\alpha]_{\mathrm{D}}{ }^{26}-147.3^{\circ}\left(c 1.0, \mathrm{CHCl}_{3}\right.$, exo : endo $=94: 6,94 \%$ ee (exo), 20\% ee (endo)).; IR (KBr) 3424, 2947, 2847, 2360, 1664, 1470, 1426, 1213, 1139, 1041, 990, 749, 704, 601, $551 \mathrm{~cm}^{-1}$; ${ }^{1} \mathrm{H}$ NMR $\left(\mathrm{CDCl}_{3}\right) \delta=1.79(1 \mathrm{H}, \mathrm{brs}), 2.69(1 \mathrm{H}, \mathrm{ddd}, J=6.3 \mathrm{~Hz}, 9.3 \mathrm{~Hz}, 16.6 \mathrm{~Hz}), 2.80$ $(1 \mathrm{H}, \mathrm{m}), 2.85-2.95(2 \mathrm{H}, \mathrm{m}), 3.33(1 \mathrm{H}, \mathrm{m}), 3.37-3.43(2 \mathrm{H}, \mathrm{m}), 3.63(1 \mathrm{H}, \mathrm{ddd}, J=6.3 \mathrm{~Hz}, 9.3 \mathrm{~Hz}, 11.0 \mathrm{~Hz})$, $3.79(1 \mathrm{H}, \mathrm{d}, J=7.1 \mathrm{~Hz}), 4.05(1 \mathrm{H}, \mathrm{dd}, J=8.5 \mathrm{~Hz}, 11.7 \mathrm{~Hz}), 7.29-7.55(5 \mathrm{H}, \mathrm{m}) ;{ }^{13} \mathrm{C} \mathrm{NMR}\left(\mathrm{CDCl}_{3}\right) \delta=$ $32.8\left(\mathrm{CH}_{2}\right), 43.9\left(\mathrm{CH}_{2}\right), 47.7(\mathrm{CH}), 48.0\left(\mathrm{CH}_{2}\right), 62.2\left(\mathrm{CH}_{2}\right), 71.6(\mathrm{CH}), 127.1(\mathrm{CH}), 127.9(\mathrm{CH}), 128.7$ (CH), 134.7 (C), 170.5 (C); MS (EI) m/z $232\left(\mathrm{M}^{+}\right)$, 173, 117, 91, 78, 49; HRMS (EI) Calcd for $\mathrm{C}_{13} \mathrm{H}_{16} \mathrm{~N}_{2} \mathrm{O}_{2}$ : $\left(\mathrm{M}^{+}\right)$, 232.1236. Found: 232.1236. Anal. Calcd for $\mathrm{C}_{13} \mathrm{H}_{16} \mathrm{~N}_{2} \mathrm{O}_{2}$ : C, 67.22; $\mathrm{H}, 6.94 ; \mathrm{N}$, 12.04\%. Found: C, 67.46; H, 6.95; N, 11.82\%. The enantiomeric excess was determined by HPLC analysis (Daicel Chiralpak AD-H, hexane : 2-PrOH $=12: 1 \mathrm{v} / \mathrm{v} \%$, detector: UV $254 \mathrm{~nm}$, Flow rate $=0.5$ $\mathrm{mL} / \mathrm{min}, 35^{\circ} \mathrm{C}, \quad \mathrm{t}_{\text {minor }}=36.8 \min ($ endo $), \mathrm{t}_{\text {major }}=44.1 \min ($ endo $), \mathrm{t}_{\text {major }}=88.6 \min ($ exo $)$, tminor $=136.5$ $\min ($ exo)).

(5R,6R)-6-Hydroxymethyl-2,2-dimethyl-5-phenyltetrahydropyrazolo[1,2-a]pyrazol-1-one

(exo-3ba'): Colorless prisms; $\mathrm{mp} 57.5-59.0{ }^{\circ} \mathrm{C}\left(\mathrm{CH}_{2} \mathrm{Cl}_{2}\right.$-hexane); $[\alpha]_{\mathrm{D}}{ }^{26}-117.7^{\circ}$ (c 1.0, $\mathrm{CHCl}_{3}$, exo : endo $=92: 8,93 \%$ ee (exo), 6\% ee (endo)); IR (KBr) 3423, 2965, 2362, 1670, 1457, 136,5 1047, 757, 705, 498 $\mathrm{cm}^{-1} ;{ }^{1} \mathrm{H} \mathrm{NMR}\left(\mathrm{CDCl}_{3}\right) \delta=1.21(3 \mathrm{H}, \mathrm{s}), 1.34(3 \mathrm{H}, \mathrm{s}), 2.04(1 \mathrm{H}, \mathrm{brs}), 2.55(1 \mathrm{H}, \mathrm{d}, J=9.5 \mathrm{~Hz}), 2.94(1 \mathrm{H}$, m), 3.31-3.42 (3H, m), $3.45(1 \mathrm{H}, \mathrm{dd}, J=2.7 \mathrm{~Hz}, 11.6 \mathrm{~Hz}), 3.66(1 \mathrm{H}, \mathrm{d}, J=6.6 \mathrm{~Hz}), 4.00(1 \mathrm{H}, \mathrm{dd}, J=8.3$ $\mathrm{Hz}, 11.6 \mathrm{~Hz}), 7.28-7.48(5 \mathrm{H}, \mathrm{m}) ;{ }^{13} \mathrm{C} \mathrm{NMR}\left(\mathrm{CDCl}_{3}\right) \delta=23.7\left(\mathrm{CH}_{3}\right), 24.1\left(\mathrm{CH}_{3}\right), 42.9\left(\mathrm{CH}_{2}\right), 46.0(\mathrm{C})$, $47.7(\mathrm{CH}), 61.8\left(\mathrm{CH}_{2}\right), 64.9\left(\mathrm{CH}_{2}\right), 72.7(\mathrm{CH}), 126.9(\mathrm{CH}), 127.7(\mathrm{CH}), 128.4(\mathrm{CH}), 134.5(\mathrm{C}), 170.7(\mathrm{C})$; Mass (EI) m/z $260\left(\mathrm{M}^{+}\right), 201,117,92,78$. Anal. Calcd for $\mathrm{C}_{15} \mathrm{H}_{20} \mathrm{~N}_{2} \mathrm{O}_{2}$ : C, 69.20; H, 7.74; N, 10.76\%. Found: C, 69.21; H, 7.78; N, 10.72\%. The enantiomeric excess was determined by HPLC analysis (Daicel Chiralpak AD-H, hexane : 2-PrOH $=12: 1 \mathrm{v} / \mathrm{v} \%$, detector: UV $254 \mathrm{~nm}$, Flow rate $=1.0 \mathrm{~mL} / \mathrm{min}$, $35{ }^{\circ} \mathrm{C}, \mathrm{t}_{\text {minor }}=16.3 \mathrm{~min}($ endo $), \mathrm{t}_{\text {major }}=19.0 \mathrm{~min}($ endo $), \mathrm{t}_{\text {major }}=29.1 \mathrm{~min}($ exo $), \mathrm{t}_{\text {minor }}=39.1 \mathrm{~min}($ exo $\left.)\right)$.

(5R,6R)-6-Hydroxymethyl-3,3-dimethyl-5-(4-chlorophenyl)tetrahydropyrazolo[1,2-a]pyrazol-1-one (exo-3cb'): Colorless prisms.; mp. $184-184.5{ }^{\circ} \mathrm{C}$ (benzene); $[\alpha]_{\mathrm{D}}{ }^{25}-67.6{ }^{\circ}$ (c 1.0, $\mathrm{MeOH}$, exo : endo = $>99$ : 1, 94\% ee (exo)).; IR (KBr) 3396, 2974, 2927, 2854, 1670, 1488, 1469, 1411, 1399, 1382, 1372, $1325,1289,1250,1225,1198,1173,1123,1104,1086 \mathrm{~cm}^{-1} ;{ }^{1} \mathrm{H} \mathrm{NMR}\left(\mathrm{CDCl}_{3}\right) \delta=1.05(3 \mathrm{H}, \mathrm{s}), 1.23(3 \mathrm{H}$, s), $1.68(1 \mathrm{H}, \mathrm{brs}), 2.47(1 \mathrm{H}, \mathrm{d}, J=16.3 \mathrm{~Hz}), 2.67(1 \mathrm{H}, \mathrm{d}, J=16.3 \mathrm{~Hz}), 2.80(1 \mathrm{H}, \mathrm{m}), 3.26-3.36(2 \mathrm{H}, \mathrm{m})$, $3.41(1 \mathrm{H}, \mathrm{dd}, J=6.6,11.0 \mathrm{~Hz}), 4.00(1 \mathrm{H}, \mathrm{dd}, J=8.2,11.0 \mathrm{~Hz}), 4.14(1 \mathrm{H}, \mathrm{d}, J=7.6 \mathrm{~Hz}), 7.30-7.43(4 \mathrm{H}$, 
$\mathrm{m}) ;{ }^{13} \mathrm{C} \mathrm{NMR}\left(\mathrm{CDCl}_{3}\right) \delta=22.3\left(\mathrm{CH}_{3}\right), 28.9\left(\mathrm{CH}_{3}\right), 43.3\left(\mathrm{CH}_{2}\right), 47.7\left(\mathrm{CH}_{2}\right), 47.8(\mathrm{CH}), 60.3(\mathrm{C}), 62.2$ $\left(\mathrm{CH}_{2}\right), 63.3(\mathrm{CH}), 128.6(\mathrm{CH}), 129.0(\mathrm{CH}), 133.5(\mathrm{C}), 135.4(\mathrm{C}), 168.4(\mathrm{C})$; Mass $(\mathrm{EI}) \mathrm{m} / \mathrm{z} 294\left(\mathrm{M}^{+}\right), 151$, 126, 111, 92, 83, 56. Anal. Calcd for $\mathrm{C}_{15} \mathrm{H}_{19} \mathrm{ClN}_{2} \mathrm{O}_{2}: \mathrm{C}, 61.12 ; \mathrm{H}, 6.50 ; \mathrm{N}, 9.72 \%$. Found: $\mathrm{C}, 60.83 ; \mathrm{H}$, 6.57; N, 9.72\%. The enantiomeric excess was determined by HPLC analysis (Daicel Chiralpak IA, hexane : 2-PrOH $=12: 1 \mathrm{v} / \mathrm{v} \%$, detector: UV $254 \mathrm{~nm}$, flow rate $=1.0 \mathrm{~mL} / \mathrm{min}, 35{ }^{\circ} \mathrm{C}, \mathrm{t}_{\text {minor }}=24.7 \mathrm{~min}$ $($ endo $), \mathrm{t}_{\text {major }}=27.5 \mathrm{~min}($ endo $), \mathrm{t}_{\text {major }}=52.0 \mathrm{~min}($ exo $), \mathrm{t}_{\text {minor }}=67.3 \mathrm{~min}($ exo $\left.)\right)$.

(5R,6R)-6-Hydroxymethyl-3,3-dimethyl-5-(4-bromophenyl)tetrahydropyrazolo[1,2-a]pyrazol-1-one

(exo-3cc'): Colorless plates; $\mathrm{mp} 202-203{ }^{\circ} \mathrm{C}$ (benzene); $[\alpha]_{\mathrm{D}}{ }^{23}-63.6^{\circ}$ (c 0.80, $\mathrm{MeOH}$, exo : endo $=>99$ : 1, 93\% ee (exo)); IR (KBr) 3370, 2967, 2941, 2910, 2876, 1665, 1486, 1449, 1427, 1407, 1387, 1370, $1351,1294,1220,1205,1177,1162,1122,1111,1072,1049,1010 \mathrm{~cm}^{-1} ;{ }^{1} \mathrm{H} \mathrm{NMR}\left(\mathrm{CDCl}_{3}\right) \delta=1.05(3 \mathrm{H}$, s), $1.24(3 \mathrm{H}, \mathrm{s}), 1.58(1 \mathrm{H}, \mathrm{brs}), 2.45(1 \mathrm{H}, \mathrm{d}, J=16.3 \mathrm{~Hz}), 2.66(1 \mathrm{H}, \mathrm{d}, J=16.3 \mathrm{~Hz}), 2.80(1 \mathrm{H}, \mathrm{m}), 3.29$ $(1 \mathrm{H}, \mathrm{ddd}, J=1.5 \mathrm{~Hz}, 4.4 \mathrm{~Hz}, 11.7 \mathrm{~Hz}), 3.31-3.47(2 \mathrm{H}, \mathrm{m}), 4.01(1 \mathrm{H}, \mathrm{dd}, J=8.5,11.7 \mathrm{~Hz}), 4.13(1 \mathrm{H}, \mathrm{d}, J$ $=7.3 \mathrm{~Hz}), 7.27-7.33(2 \mathrm{H}, \mathrm{m}), 7.46-7.54(2 \mathrm{H}, \mathrm{m}) ;{ }^{13} \mathrm{C} \mathrm{NMR}\left(\mathrm{CDCl}_{3}\right) \delta=22.5\left(\mathrm{CH}_{3}\right), 29.0\left(\mathrm{CH}_{3}\right), 43.3$ $\left(\mathrm{CH}_{2}\right), 47.6\left(\mathrm{CH}_{2}\right), 47.8(\mathrm{CH}), 60.4(\mathrm{C}), 62.4\left(\mathrm{CH}_{2}\right), 63.6(\mathrm{CH}), 121.7(\mathrm{C}), 129.4(\mathrm{CH}), 131.5(\mathrm{CH}), 136.0$ (C), 168.7 (C); Mass (EI) m/z $338\left(\mathrm{M}^{+}\right)$, 138, 126, 111, 83, 56. Anal. Calcd for $\mathrm{C}_{15} \mathrm{H}_{19} \mathrm{BrN}_{2} \mathrm{O}_{2}$ : C, 53.11; H, 5.65; N, 8.26\%. Found: C, 53.03; H, 5.65; N, 8.26\%.; The enantiomeric excess was determined by HPLC analysis (Daicel Chiralpak AD-H, hexane : 2-PrOH $=12: 1 \mathrm{v} / \mathrm{v} \%$, detector: UV $254 \mathrm{~nm}$, flow rate $=1.0 \mathrm{~mL} / \mathrm{min}, 35^{\circ} \mathrm{C}, \mathrm{t}_{\text {minor }}=9.1 \mathrm{~min}($ endo $), \mathrm{t}_{\text {major }}=11.4 \min ($ endo $), \mathrm{t}_{\text {major }}=20.3 \mathrm{~min}$ $($ exo $), \mathrm{t}_{\text {minor }}=26.9 \min ($ exo $\left.)\right)$.

\section{(5R,6R)-6-Hydroxymethyl-3,3-dimethyl-5-(4-cyanophenyl)tetrahydropyrazolo[1,2-a]pyrazol-1-one}

(exo-3cd'): Colorless needles; mp 163-164.5 ${ }^{\circ} \mathrm{C}$ (benzene); $[\alpha]_{\mathrm{D}}{ }^{23}-98.4^{\circ}$ (c 1.0, $\mathrm{MeOH}$, exo : endo $=$ $>99$ : 1, 96\% ee (exo)); IR (KBr) 3379, 2976, 2953, 2934, 2911, 2892, 2225, 1671, 1605, 1504, 1474, $1443,1421,1371,1294,1252,1229,1181,1157,1122,1111,1075,1051,1018 \mathrm{~cm}^{-1} ;{ }^{1} \mathrm{H}$ NMR $\left(\mathrm{CDCl}_{3}\right) \delta$ $=1.04(3 \mathrm{H}, \mathrm{s}), 1.25(3 \mathrm{H}, \mathrm{s}), 1.68(1 \mathrm{H}, \mathrm{brs}), 2.46(1 \mathrm{H}, \mathrm{d}, J=16.4 \mathrm{~Hz}), 2.66(1 \mathrm{H}, \mathrm{d}, J=16.4 \mathrm{~Hz}), 2.87(1 \mathrm{H}$, m), $3.24(1 \mathrm{H}, \mathrm{m}), 3.28(1 \mathrm{H}, \mathrm{ddd}, J=1.2,4.6,11.7 \mathrm{~Hz}), 3.36(1 \mathrm{H}, \mathrm{dd}, J=7.5 \mathrm{~Hz}, 10.7 \mathrm{~Hz}), 4.05(1 \mathrm{H}, \mathrm{dd}$, $J=8.5 \mathrm{~Hz}, 11.7 \mathrm{~Hz}), 4.21(1 \mathrm{H}, \mathrm{d}, J=7.8 \mathrm{~Hz}), 7.50-7.61(2 \mathrm{H}, \mathrm{m}), 7.63-7.73(2 \mathrm{H}, \mathrm{m}) ;{ }^{13} \mathrm{C} \mathrm{NMR}$ $\left(\mathrm{CDCl}_{3}\right) \delta=22.3\left(\mathrm{CH}_{3}\right), 28.7\left(\mathrm{CH}_{3}\right), 43.4\left(\mathrm{CH}_{2}\right), 47.2\left(\mathrm{CH}_{2}\right), 47.5(\mathrm{CH}), 60.4(\mathrm{C}), 61.7\left(\mathrm{CH}_{2}\right), 63.0(\mathrm{CH})$, $111.3(\mathrm{C}), 118.2(\mathrm{C}), 128.4(\mathrm{CH}), 131.8(\mathrm{CH}), 142.9(\mathrm{C}), 168.7(\mathrm{C})$.; Mass (EI) m/z $285\left(\mathrm{M}^{+}\right), 111,83,56$. Anal. Calcd for $\mathrm{C}_{16} \mathrm{H}_{19} \mathrm{~N}_{3} \mathrm{O}_{2}$ : C, 67.35; H, 6.71; N, 14.73\%. Found: C, 67.15; H, 6.89; N, 14.75\%. The enantiomeric excess was determined by HPLC analysis (Daicel Chiralpak IA, hexane $: 2-\operatorname{PrOH}=5: 1$ $\mathrm{v} / \mathrm{v} \%$, detector: UV $254 \mathrm{~nm}$, flow rate $=0.4 \mathrm{~mL} / \mathrm{min}, 35{ }^{\circ} \mathrm{C}, \mathrm{t}_{\text {minor }}=22.4 \min$ (endo), $\mathrm{t}_{\text {major }}=25.0 \mathrm{~min}$ (endo), $\mathrm{t}_{\text {major }}=37.0 \mathrm{~min}($ exo $), \mathrm{t}_{\text {minor }}=46.0 \min ($ exo $\left.)\right)$. 
(5R,6R)-6-Hydroxymethyl-3,3-dimethyl-5-(4-nitrophenyl)tetrahydropyrazolo[1,2-a]pyrazol-1-one

(exo-3ce'): Pale yellow leaflets; $\mathrm{mp} 161.5-163{ }^{\circ} \mathrm{C}$ (benzene); $[\alpha]_{\mathrm{D}}^{23}-55.3^{\circ}(c 0.80, \mathrm{MeOH}$, exo : endo= $>99$ : 1, 75\% ee (exo)).; IR (KBr) 3384, 2976, 2963, 2944, 2897, 1646, 1597, 1525, 1465, 1421, 1385, 1370, 1345, 1314, 1296, 1228, 1108, 1074, 1053, $1035 \mathrm{~cm}^{-1} ;{ }^{1} \mathrm{H}$ NMR $\left(\mathrm{CDCl}_{3}\right) \delta=1.05(3 \mathrm{H}, \mathrm{s}), 1.25(3 \mathrm{H}$, s), $2.20(1 \mathrm{H}, \mathrm{brs}), 2.46(1 \mathrm{H}, \mathrm{d}, J=16.8 \mathrm{~Hz}), 2.67(1 \mathrm{H}, \mathrm{d}, J=16.3 \mathrm{~Hz}), 2.90(1 \mathrm{H}, \mathrm{m}), 3.20(1 \mathrm{H}, \mathrm{dd}, J=5.4$, $10.5 \mathrm{~Hz}), 3.29(1 \mathrm{H}, \mathrm{ddd}, J=1.2,4.6,12.0 \mathrm{~Hz}), 3.37(1 \mathrm{H}, \mathrm{dd}, J=7.8,10.5 \mathrm{~Hz}), 4.04(1 \mathrm{H}, \mathrm{dd}, J=8.3,12.0$ $\mathrm{Hz}), 4.27(1 \mathrm{H}, \mathrm{d}, J=8.1 \mathrm{~Hz}), 7.56-7.71(2 \mathrm{H}, \mathrm{m}), 8.14-8.34(2 \mathrm{H}, \mathrm{m}) ;{ }^{13} \mathrm{C} \mathrm{NMR}\left(\mathrm{CDCl}_{3}\right) \delta=22.8\left(\mathrm{CH}_{3}\right)$, $29.1\left(\mathrm{CH}_{3}\right), 43.5\left(\mathrm{CH}_{2}\right), 47.1\left(\mathrm{CH}_{2}\right), 47.8(\mathrm{CH}), 60.4(\mathrm{C}), 62.1\left(\mathrm{CH}_{2}\right), 63.4(\mathrm{CH}), 123.5(\mathrm{CH}), 128.7$ $(\mathrm{CH}), 145.1(\mathrm{C}), 147.3(\mathrm{C}), 169.6(\mathrm{C})$; Mass (EI) m/z $305\left(\mathrm{M}^{+}\right), 111,78$. Anal. Calcd for $\mathrm{C}_{15} \mathrm{H}_{19} \mathrm{~N}_{3} \mathrm{O}_{4}$ : C, 59.01; H, 6.27; N, 13.76\%. Found: C, 59.21; H, 6.17; N, 13.66\%; The enantiomeric excess was determined by HPLC analysis (Daicel Chiralpak AD-H, hexane : 2-PrOH $=12: 1 \mathrm{v} / \mathrm{v} \%$, detector: UV $254 \mathrm{~nm}$, flow rate $=1.0 \mathrm{~mL} / \mathrm{min}, 35^{\circ} \mathrm{C}, \mathrm{t}_{\text {minor }}=18.1 \min ($ endo $), \mathrm{t}_{\text {major }}=24.8 \min ($ endo $), \mathrm{t}_{\text {major }}=37.3 \mathrm{~min}$ $($ exo $), \mathrm{t}_{\text {minor }}=64.1 \min ($ exo $\left.)\right)$.

(5R,6R)-6-Hydroxymethyl-3,3-dimethyl-5-p-toyltetrahydropyrazolo[1,2-a]pyrazol-1-one (exo-3cg'): Colorless needles; mp 187-187.5 ${ }^{\circ} \mathrm{C}$ (benzene); $[\alpha]_{\mathrm{D}}^{23}-67.7^{\circ}$ (c $0.80, \mathrm{MeOH}$, exo : endo $=>99: 1,97 \%$ ee (exo)); IR (KBr) 3368, 3094, 3060, 3028, 3010, 2963, 2926, 2875, 1685, 1632, 1515, 1474, 1449, 1431, $1398,1371,1297,1256,1222,1205,1182,1167,1125,1078,1053 \mathrm{~cm}^{-1} ;{ }^{1} \mathrm{H} \mathrm{NMR}\left(\mathrm{CDCl}_{3}\right) \delta=1.06(3 \mathrm{H}$, s), $1.23(3 \mathrm{H}, \mathrm{s}), 1.71(1 \mathrm{H}, \mathrm{brs}), 2.35(3 \mathrm{H}, \mathrm{s}), 2.46(1 \mathrm{H}, \mathrm{d}, J=16.3 \mathrm{~Hz}), 2.68(1 \mathrm{H}, \mathrm{d}, J=16.3 \mathrm{~Hz}), 2.79$ $(1 \mathrm{H}, \mathrm{m}), 3.28(1 \mathrm{H}, \mathrm{dd}, J=3.7 \mathrm{~Hz}, 11.7 \mathrm{~Hz}), 3.38-3.46(2 \mathrm{H}, \mathrm{m}), 3.97(1 \mathrm{H}, \mathrm{dd}, J=8.5 \mathrm{~Hz}, 11.7 \mathrm{~Hz}), 4.14$ $(1 \mathrm{H}, \mathrm{d}, J=7.3 \mathrm{~Hz}), 7.14-7.20(2 \mathrm{H}, \mathrm{m}), 7.27-7.34(2 \mathrm{H}, \mathrm{m}) ;{ }^{13} \mathrm{C} \mathrm{NMR}\left(\mathrm{CDCl}_{3}\right) \delta=21.2\left(\mathrm{CH}_{3}\right), 22.1$ $\left(\mathrm{CH}_{3}\right), 28.7\left(\mathrm{CH}_{3}\right), 42.9\left(\mathrm{CH}_{2}\right), 47.9\left(\mathrm{CH}_{2}\right), 47.9(\mathrm{CH}), 60.3(\mathrm{C}), 62.5\left(\mathrm{CH}_{2}\right), 64.1(\mathrm{CH}), 127.5(\mathrm{CH})$, $129.0(\mathrm{CH}), 133.3(\mathrm{C}), 137.4(\mathrm{C}), 167.9(\mathrm{C})$; Mass (EI) m/z $274\left(\mathrm{M}^{+}\right), 131,111,83,56$; Anal. Calcd for $\mathrm{C}_{16} \mathrm{H}_{22} \mathrm{~N}_{2} \mathrm{O}_{2}$ : C, 70.04; H, 8.08; N, 10.21\%. Found: C, 70.04; H, 8.07; N, 10.23\%.; The enantiomeric excess was determined by HPLC analysis (Daicel Chiralpak IA, hexane : 2-PrOH $=12: 1 \mathrm{v} / \mathrm{v} \%$, detector: UV $254 \mathrm{~nm}$, flow rate $=0.5 \mathrm{~mL} / \mathrm{min}, 35^{\circ} \mathrm{C}, \mathrm{t}_{\text {minor }}=21.5 \min ($ endo $), \mathrm{t}_{\text {major }}=23.7 \min ($ endo $), \mathrm{t}_{\text {major }}=39.6$ $\min ($ exo $), \mathrm{t}_{\text {minor }}=47.3 \min ($ exo $\left.)\right)$.

\section{(5R,6R)-6-Hydroxymethyl-5-(4-methoxyphenyl)-3,3-dimethyltetrahydropyrazolo[1,2-a]pyrazol-1-}

one (exo-3ch'): Colorless needles; mp $192{ }^{\circ} \mathrm{C}$ (benzene); $[\alpha]_{\mathrm{D}}{ }^{26}-70.5^{\circ}$ (c $0.80, \mathrm{MeOH}$, exo : endo = $>99$ : 1, 98\% ee (exo)).; IR (KBr) 3344, 2989, 2972, 2951, 2892, 2878, 2834, 1683, 1632, 1615, 1583, 1516, 1473, 1465, 1443, 1431, 1402, 1369, 1296, 1256, 1221, 1204, 1170, 1126, 1109, 1078, 1053, 1036, $\mathrm{cm}^{-1} ;{ }^{1} \mathrm{H}$ NMR $\left(\mathrm{CDCl}_{3}\right) \delta=1.07(3 \mathrm{H}, \mathrm{s}), 1.21(3 \mathrm{H}, \mathrm{s}), 1.77(1 \mathrm{H}, \mathrm{brs}), 2.44(1 \mathrm{H}, \mathrm{d}, J=16.3 \mathrm{~Hz}), 2.68(1 \mathrm{H}$, $\mathrm{d}, J=16.3 \mathrm{~Hz}), 2.77(1 \mathrm{H}, \mathrm{m}), 3.29(1 \mathrm{H}, \mathrm{dd}, J=3.7 \mathrm{~Hz}, 11.7 \mathrm{~Hz}), 3.39-3.50(2 \mathrm{H}, \mathrm{m}), 3.82(3 \mathrm{H}, \mathrm{s}), 3.97$ 
$(1 \mathrm{H}, \mathrm{dd}, J=8.5 \mathrm{~Hz}, 11.7 \mathrm{~Hz}), 4.13(1 \mathrm{H}, \mathrm{d}, J=7.3 \mathrm{~Hz}), 6.84-6.96(2 \mathrm{H}, \mathrm{m}), 7.28-7.38(2 \mathrm{H}, \mathrm{m}) ;{ }^{13} \mathrm{C} \mathrm{NMR}$ $\left(\mathrm{CDCl}_{3}\right) \delta=22.0\left(\mathrm{CH}_{3}\right), 28.7\left(\mathrm{CH}_{3}\right), 43.0\left(\mathrm{CH}_{2}\right), 48.0\left(\mathrm{CH}_{2}\right), 47.8(\mathrm{CH}), 55.1\left(\mathrm{CH}_{3}\right), 60.2(\mathrm{C}), 62.2$ $\left(\mathrm{CH}_{2}\right), 63.3(\mathrm{CH}), 113.6(\mathrm{CH}), 128.0(\mathrm{C}), 128.7(\mathrm{CH}), 158.8(\mathrm{C}), 167.5(\mathrm{C})$; Mass $(\mathrm{EI}) \mathrm{m} / \mathrm{z} 290\left(\mathrm{M}^{+}\right), 147$, 111, 83, 56. Anal. Calcd for $\mathrm{C}_{16} \mathrm{H}_{22} \mathrm{~N}_{2} \mathrm{O}_{3}: \mathrm{C}, 66.18 ; \mathrm{H}, 7.64 ; \mathrm{N}, 9.65 \%$. Found: C, 66.07; H, 7.99; N, 9.41\%. The enantiomeric excess was determined by HPLC analysis (Daicel Chiralpak IA, hexane : 2-PrOH $=12: 1 \mathrm{v} / \mathrm{v} \%$, detector: UV $254 \mathrm{~nm}$, flow rate $=0.5 \mathrm{~mL} / \mathrm{min}, 35^{\circ} \mathrm{C}, \mathrm{t}_{\text {minor }}=30.8 \mathrm{~min}$ (endo), $\mathrm{t}_{\text {major }}=33.5 \min ($ endo $), \mathrm{t}_{\text {major }}=60.4 \min ($ exo $), \mathrm{t}_{\text {minor }}=70.6 \min ($ exo $\left.)\right)$.

\section{(5R,6R)-6-Hydroxymethyl-3,3-dimethyl-5-(2-naphthyl)tetrahydropyrazolo[1,2-a]pyrazol-1-one}

(exo-3ci'): Pale red prisms; mp 260-261 ${ }^{\circ} \mathrm{C}(\mathrm{MeOH}) ;[\alpha]_{\mathrm{D}}{ }^{26}-43.7^{\circ}$ (c 0.40, $\mathrm{MeOH}$, exo : endo $=>99: 1$, 95\% ee (exo)).; IR (KBr) 3351, 2990, 2970, 2925, 2877, 1671, 1632, 1599, 1507, 1473, 1446, 1428, 1402 , $1388,1365,1306,1294,1252,1221,1202,1174,1124,1109,1079,1050 \mathrm{~cm}^{-1} ;{ }^{1} \mathrm{H}$ NMR $\left(\mathrm{CDCl}_{3}\right) \delta=$ $1.09(3 \mathrm{H}, \mathrm{s}), 1.27(3 \mathrm{H}, \mathrm{s}), 1.60(1 \mathrm{H}, \mathrm{brs}), 2.49(1 \mathrm{H}, \mathrm{d}, J=16.4 \mathrm{~Hz}), 2.71(1 \mathrm{H}, \mathrm{d}, J=16.4 \mathrm{~Hz}), 2.90(1 \mathrm{H}$, m), $3.36(1 \mathrm{H}, \mathrm{m}), 3.39$ (1H, dd, $J=5.6 \mathrm{~Hz}, 11.2 \mathrm{~Hz}), 3.46(1 \mathrm{H}, \mathrm{dd}, J=6.3 \mathrm{~Hz}, 11.2 \mathrm{~Hz}), 4.05(1 \mathrm{H}, \mathrm{dd}, J$ $=8.1 \mathrm{~Hz}, 11.2 \mathrm{~Hz}), 4.35(1 \mathrm{H}, \mathrm{d}, J=7.3 \mathrm{~Hz}), 7.46-7.61(3 \mathrm{H}, \mathrm{m}), 7.77-7.96(4 \mathrm{H}, \mathrm{m}) ;{ }^{13} \mathrm{C} \mathrm{NMR}\left(\mathrm{CDCl}_{3}\right)$ $\delta=22.8\left(\mathrm{CH}_{3}\right), 29.2\left(\mathrm{CH}_{3}\right), 43.2\left(\mathrm{CH}_{2}\right), 47.7\left(\mathrm{CH}_{2}\right), 48.3(\mathrm{CH}), 60.3(\mathrm{C}), 62.7\left(\mathrm{CH}_{2}\right), 64.7(\mathrm{CH}), 125.3$ $(\mathrm{CH}), 126.2(\mathrm{CH}), 126.4(\mathrm{CH}), 126.8(\mathrm{CH}), 127.6(\mathrm{CH}), 127.7(\mathrm{CH}), 128.2(\mathrm{CH}), 132.9(\mathrm{C}), 133.0(\mathrm{C})$, 134.3 (C); Mass (EI) m/z $310\left(\mathrm{M}^{+}\right), 167,111,83,56$. Anal. Calcd for $\mathrm{C}_{19} \mathrm{H}_{22} \mathrm{~N}_{2} \mathrm{O}_{2}$ : C, 73.52; $\mathrm{H}, 7.14 ; \mathrm{N}$, 9.03\%. Found: C, 73.39; H, 7.33; N, 8.97\%. The enantiomeric excess was determined by HPLC analysis (Daicel Chiralpak IA, hexane : 2-PrOH $=12: 1 \mathrm{v} / \mathrm{v} \%$, detector: UV $254 \mathrm{~nm}$, flow rate $=0.5$ $\mathrm{mL} / \mathrm{min}, 35{ }^{\circ} \mathrm{C}, \mathrm{t}_{\text {minor }}=26.2 \min ($ endo $), \mathrm{t}_{\text {major }}=31.1 \mathrm{~min}($ endo $), \mathrm{t}_{\text {major }}=55.2 \min ($ exo $), \mathrm{t}_{\text {minor }}=74.1 \mathrm{~min}$ (exo)).

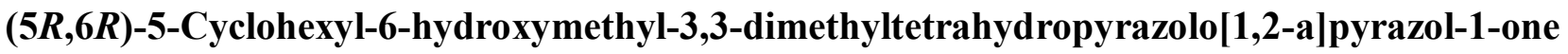

(exo-3cj'): Pale yellow oil; $[\alpha]_{\mathrm{D}}^{23}+40.6^{\circ}$ (c 0.60, $\mathrm{MeOH}$, exo : endo $=>99: 1,88 \%$ ee (exo)).; IR (neat) 2984, 2932, 2856, 2361, 1680, 1452, 1371, $1113 \mathrm{~cm}^{-1} ;{ }^{1} \mathrm{H}$ NMR $\left(\mathrm{CDCl}_{3}\right) \delta=1.15-1.70(11 \mathrm{H}, \mathrm{m}), 1.26$ $(6 \mathrm{H}, \mathrm{s}), 2.17(1 \mathrm{H}, \mathrm{d}, J=14.9 \mathrm{~Hz}), 2.62(1 \mathrm{H}, \mathrm{m}), 2.79(1 \mathrm{H}, \mathrm{d}, J=14.9 \mathrm{~Hz}), 2.99-3.09$ (2H, m), 3.81-3.84 $(2 \mathrm{H}, \mathrm{m}), 3.99(1 \mathrm{H}, \mathrm{dd}, J=8.3 \mathrm{~Hz}, 11.2 \mathrm{~Hz})$, The signal of $\mathrm{OH}$ could not be identified; Mass (EI) m/z 266 $\left(\mathrm{M}^{+}\right)$, 141; HRMS (EI) Found: $\mathrm{m} / \mathrm{z}$ 266.1950. Calcd for $\mathrm{C}_{15} \mathrm{H}_{26} \mathrm{~N}_{2} \mathrm{O}_{2}\left(\mathrm{M}^{+}\right)$: 266.1994. Anal. Calcd for $\mathrm{C}_{15} \mathrm{H}_{26} \mathrm{~N}_{2} \mathrm{O}_{2}$ : C, 67.63; H, 9.84; N, 10.52\%. Found: C, 68.21; H, 9.85; N, 9.93\% (Satisfactory elemental analysis was not obtained). The enantiomeric excess was determined by HPLC analysis (Daicel Chiralpak IA, hexane : 2 -PrOH $=12: 1 \mathrm{v} / \mathrm{v} \%$, detector: $U V 254 \mathrm{~nm}$, flow rate $=0.5 \mathrm{~mL} / \mathrm{min}, 35^{\circ} \mathrm{C}, \mathrm{t}_{\text {minor }}$ $=19.6 \min ($ endo $), \mathrm{t}_{\text {major }}=20.1 \mathrm{~min}($ endo $), \mathrm{t}_{\text {major }}=31.2 \min ($ exo $), \mathrm{t}_{\text {minor }}=34.0 \min ($ exo $\left.)\right)$. 
(5R,6S)-6-Hydroxymethyl-5-phenyl-tetrahydropyrazolo[1,2-a]pyrazol-1-one (endo-3aa'): Pale orange leaflets; $\mathrm{mp} 142-143{ }^{\circ} \mathrm{C}$ (benzene-hexane); $[\alpha]_{\mathrm{D}}{ }^{26}-14.1^{\circ}$ (c 1.0, $\mathrm{CHCl}_{3}$, endo : exo $=94: 6,83 \%$ ee (endo), 84\% ee (exo)).; IR (KBr) 3387, 3028, 2935, 2852, 2356, 1680, 1471, 1411, 1306, 1251, 1200, 1160, 1129, 1060, 1019, 837, 797, 754, 699, 610, $581 \mathrm{~cm}^{-1} ;{ }^{1} \mathrm{H}$ NMR $\left(\mathrm{CDCl}_{3}\right) \delta=2.52(1 \mathrm{H}$, brs), 2.69-2.77 (3H, m), $2.93(1 \mathrm{H}, \mathrm{dt}, J=11.2 \mathrm{~Hz}, 8.8 \mathrm{~Hz}), 3.41(1 \mathrm{H}, \mathrm{d}, J=9.3 \mathrm{~Hz}), 3.45(1 \mathrm{H}, \mathrm{dt}, J=11.2 \mathrm{~Hz}$, $7.8 \mathrm{~Hz}), 3.52(1 \mathrm{H}, \mathrm{dd}, J=9.8 \mathrm{~Hz}, 11.2 \mathrm{~Hz}), 3.61(1 \mathrm{H}, \mathrm{dd}, J=5.0 \mathrm{~Hz}, 11.5 \mathrm{~Hz}), 3.71(1 \mathrm{H}, \mathrm{dd}, J=3.8 \mathrm{~Hz}$, $11.5 \mathrm{~Hz}), 3.82(1 \mathrm{H}, \mathrm{dd}, J=6.6 \mathrm{~Hz}, 11.2 \mathrm{~Hz}), 7.32-7.41(5 \mathrm{H}, \mathrm{m}) ;{ }^{13} \mathrm{C} \mathrm{NMR}\left(\mathrm{CDCl}_{3}\right) \delta=32.8\left(\mathrm{CH}_{2}\right), 43.2$ $\left(\mathrm{CH}_{2}\right), 47.5\left(\mathrm{CH}_{2}\right), 52.7(\mathrm{CH}), 60.0\left(\mathrm{CH}_{2}\right), 71.0(\mathrm{CH}), 127.6(\mathrm{CH}), 128.0(\mathrm{CH}), 128.8(\mathrm{CH}), 137.1(\mathrm{C})$, 170.3 (C); MS (EI) m/z $232\left(\mathrm{M}^{+}\right)$, 173, 117, 91, 78, 56; HRMS (EI) Calcd for $\mathrm{C}_{13} \mathrm{H}_{16} \mathrm{~N}_{2} \mathrm{O}_{2}$ : $\left(\mathrm{M}^{+}\right)$, 232.1212. Found: 232.1236. Anal. Calcd for $\mathrm{C}_{19} \mathrm{H}_{20} \mathrm{~N}_{4} \mathrm{O}_{4}: \mathrm{C}, 67.22 ; \mathrm{H}, 6.94 ; \mathrm{N}, 12.04 \%$. Found: $\mathrm{C}$, 67.99; H, 7.39; N, 10.61\% (Satisfactory elemental analysis was not obtained). The enantiomeric excess was determined by HPLC analysis (Daicel Chiralpak AD-H, hexane : 2-PrOH $=12: 1 \mathrm{v} / \mathrm{v} \%$, detector: $\mathrm{UV} 254 \mathrm{~nm}$, Flow rate $=0.5 \mathrm{~mL} / \mathrm{min}, 35^{\circ} \mathrm{C}, \mathrm{t}_{\text {minor }}=35.0 \mathrm{~min}($ endo $), \mathrm{t}_{\text {major }}=41.9 \mathrm{~min}($ endo $), \mathrm{t}_{\text {major }}=84.3$ $\min ($ exo $)$, tminor $=130.0 \min ($ exo $))$.

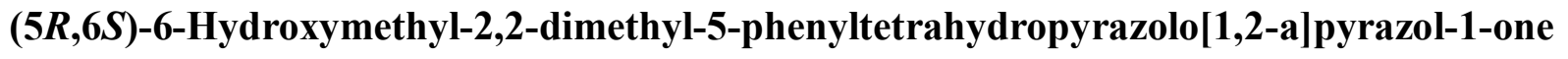

(endo-3ba'): Colorless prisms; mp $129-130.5^{\circ} \mathrm{C}\left(\mathrm{CH}_{2} \mathrm{Cl}_{2}\right.$-hexane); $[\alpha]_{\mathrm{D}}{ }^{26}-27.6^{\circ}$ (c $0.80, \mathrm{CHCl}_{3}$, endo : exo $=87: 13,78 \%$ ee (endo), 83\% ee (exo)).; IR (KBr) 3440, 3031, 2971, 2927, 2838, 2360, 1694, 1469, 1405, 1367, 1345, 1306, 1254, 1191, 1127, 1074, 1038, 995, 949, 839, 775, 744, 697, 602, $556 \mathrm{~cm}^{-1} ;{ }^{1} \mathrm{H}$ $\operatorname{NMR}\left(\mathrm{CDCl}_{3}\right) \delta=1.21(3 \mathrm{H}, \mathrm{s}), 1.29(3 \mathrm{H}, \mathrm{s}), 2.59(1 \mathrm{H}, \mathrm{brs}), 2.62(1 \mathrm{H}, \mathrm{d}, J=9.5 \mathrm{~Hz}), 2.75(1 \mathrm{H}, \mathrm{m}), 3.21$ $(1 \mathrm{H}, \mathrm{d}, J=9.5 \mathrm{~Hz}), 3.37(1 \mathrm{H}, \mathrm{d}, J=9.3 \mathrm{~Hz}), 3.53-3.65(2 \mathrm{H}, \mathrm{m}), 3.72(1 \mathrm{H}, \mathrm{dd}, J=3.6 \mathrm{~Hz}, 11.2 \mathrm{~Hz}), 3.83$ $(1 \mathrm{H}, \mathrm{dd}, J=8.0 \mathrm{~Hz}, 11.2 \mathrm{~Hz}), 7.23-7.45(5 \mathrm{H}, \mathrm{m}) ;{ }^{13} \mathrm{C} \mathrm{NMR}\left(\mathrm{CDCl}_{3}\right) \delta=23.8\left(\mathrm{CH}_{3}\right), 24.1\left(\mathrm{CH}_{3}\right), 42.4$ $\left(\mathrm{CH}_{2}\right), 52.6(\mathrm{CH}), 59.8\left(\mathrm{CH}_{2}\right), 64.5\left(\mathrm{CH}_{2}\right), 72.4(\mathrm{CH}), 127.6(\mathrm{CH}), 128.0(\mathrm{CH}), 128.5(\mathrm{CH}), 137.0(\mathrm{C})$, 170.7 (C); Mass (EI) m/z $260\left(\mathrm{M}^{+}\right), 201,117,91,56$. Anal. Calcd for $\mathrm{C}_{15} \mathrm{H}_{20} \mathrm{~N}_{2} \mathrm{O}_{2}$ : C, 69.20; H, 7.74; N, 10.76\%. Found: C, 68.88; H, 7.97; N, 10.86\%. The enantiomeric excess was determined by HPLC analysis (Daicel Chiralpak AD-H, hexane : 2-PrOH $=12: 1 \mathrm{v} / \mathrm{v} \%$, detector: UV $254 \mathrm{~nm}$, Flow rate $=0.5$ $\mathrm{mL} / \mathrm{min}, 35{ }^{\circ} \mathrm{C}, \mathrm{t}_{\text {minor }}=16.4 \mathrm{~min}($ endo $), \mathrm{t}_{\text {major }}=18.9 \min ($ endo $), \mathrm{t}_{\text {major }}=29.1 \mathrm{~min}($ exo $), \mathrm{t}_{\text {minor }}=39.2 \mathrm{~min}$ (exo).

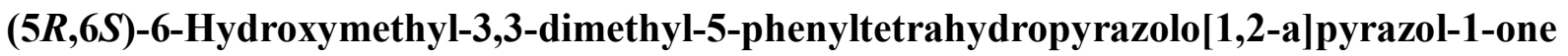

(endo-3ca'): Colorless leaflets; $\mathrm{mp} 142-143{ }^{\circ} \mathrm{C}\left(\mathrm{CH}_{2} \mathrm{Cl}_{2}\right.$-hexane); $[\alpha]_{\mathrm{D}}{ }^{26}+23.6^{\circ}$ (c 1.0, $\mathrm{CHCl}_{3}$, endo : exo $=90: 10,79 \%$ ee (endo), 69\% ee (exo)); IR ( $\mathrm{KBr}) 3437,3029,2970,2935,2872,2360,1687,1461,1379$, 1292, 1252, 1229, 1177, 1060, 817, 753, 701, 594, $543 \mathrm{~cm}^{-1} ;{ }^{1} \mathrm{H} \mathrm{NMR}\left(\mathrm{CDCl}_{3}\right) \delta=1.01(6 \mathrm{H}, \mathrm{s}), 1.97(1 \mathrm{H}$, brs), $2.47(1 \mathrm{H}, \mathrm{d}, J=16.6 \mathrm{~Hz}), 2.63(1 \mathrm{H}, \mathrm{d}, J=16.6 \mathrm{~Hz}), 2.67(1 \mathrm{H}, \mathrm{m}), 3.50-3.63(2 \mathrm{H}, \mathrm{m}), 3.64-3.76(2 \mathrm{H}$, 
m), $3.78(1 \mathrm{H}, \mathrm{d}, J=9.3 \mathrm{~Hz}), 7.27-7.44(5 \mathrm{H}, \mathrm{m}) ;{ }^{13} \mathrm{C} \mathrm{NMR}\left(\mathrm{CDCl}_{3}\right) \delta=22.7\left(\mathrm{CH}_{3}\right), 28.6\left(\mathrm{CH}_{3}\right), 42.5$ $\left(\mathrm{CH}_{2}\right), 47.8\left(\mathrm{CH}_{2}\right), 53.7(\mathrm{CH}), 59.9\left(\mathrm{CH}_{2}\right), 63.2(\mathrm{CH}), 127.6(\mathrm{CH}), 127.7(\mathrm{CH}), 128.4(\mathrm{CH}), 139.4(\mathrm{C})$, 168.1 (C); Mass (EI) m/z $260\left(\mathrm{M}^{+}\right), 201,138,117,91,56$. Anal. Calcd for $\mathrm{C}_{15} \mathrm{H}_{20} \mathrm{~N}_{2} \mathrm{O}_{2}$ : C, 69.20; H, 7.74; N, 10.76\%. Found: C, 69.17; H, 7.82; N, 10.72\%. The enantiomeric excess was determined by HPLC analysis (Daicel Chiralpak IA, $\mathrm{CH}_{2} \mathrm{Cl}_{2}$ : hexane : 2-PrOH $=20: 10: 1 \mathrm{v} / \mathrm{v} \%$, detector: UV $254 \mathrm{~nm}$, flow rate $=0.3 \mathrm{~mL} / \mathrm{min}, 25^{\circ} \mathrm{C}, \mathrm{t}_{\text {major }}$ and $\mathrm{t}_{\text {minor }}=40.5 \min ($ exo $), \mathrm{t}_{\text {major }}=44.0 \min ($ endo $), \mathrm{t}_{\text {minor }}=47.4 \mathrm{~min}$ (endo)).

(5R,6S)-5-(4-Chlorophenyl)-6-hydroxymethyltetrahydropyrazolo[1,2-a]pyrazol-1-one (endo-3ab'): Colorless needles; mp 200.5-201 ${ }^{\circ} \mathrm{C}$ (benzene); $[\alpha]_{\mathrm{D}}{ }^{26}-17.5^{\circ}$ (c $0.80, \mathrm{MeOH}$, endo : exo $=99: 1,74 \%$ ee (endo)); IR (KBr) 3289, 3041, 2972, 2945, 2928, 2888, 2865, 1645, 1498, 1460, 1419, 1380, 1347, 1303, 1204, 1182, 1119, $1090 \mathrm{~cm}-1 ;{ }^{1} \mathrm{H}$ NMR $\left(\mathrm{CDCl}_{3}\right) \delta=2.22(1 \mathrm{H}, \mathrm{brs}), 2.60-2.79(3 \mathrm{H}, \mathrm{m}), 2.92(1 \mathrm{H}, \mathrm{dt}, J=$ 11.2, $8.4 \mathrm{~Hz}), 3.40(1 \mathrm{H}, \mathrm{d}, J=8.8 \mathrm{~Hz}), 3.43-3.56(2 \mathrm{H}, \mathrm{m}), 3.60(1 \mathrm{H}, \mathrm{dd}, J=5.4,11.2 \mathrm{~Hz}), 3.70(1 \mathrm{H}, \mathrm{dd}, J$ $=3.9,11.2 \mathrm{~Hz}), 3.81(1 \mathrm{H}, \mathrm{dd}, J=6.1,11.2 \mathrm{~Hz}), 7.35(5 \mathrm{H}, \mathrm{brs}) ;{ }^{13} \mathrm{C} \mathrm{NMR}\left(\mathrm{CDCl}_{3}\right) \delta=32.8\left(\mathrm{CH}_{2}\right), 43.2$ $\left(\mathrm{CH}_{2}\right), 47.4\left(\mathrm{CH}_{2}\right), 53.0(\mathrm{CH}), 59.9\left(\mathrm{CH}_{2}\right), 70.3(\mathrm{CH}), 128.8(\mathrm{CH}), 129.0(\mathrm{CH}), 133.9(\mathrm{C}), 135.9(\mathrm{C})$, 170.9 (C); Mass (EI) m/z $266\left(\mathrm{M}^{+}\right), 151,115,98,56$. Anal. Calcd for $\mathrm{C}_{13} \mathrm{H}_{15} \mathrm{ClN}_{2} \mathrm{O}_{2}$ : C, 58.54; H, 5.67; N, 10.50\%. Found: C, 58.61; H, 5.63; N, 10.47\%. The enantiomeric excess was determined by HPLC analysis (Daicel Chiralpak AD-H, hexane : 2-PrOH $=20: 1 \mathrm{v} / \mathrm{v} \%$, detector: UV $254 \mathrm{~nm}$, Flow rate $=0.5$ $\mathrm{mL} / \mathrm{min}, 35^{\circ} \mathrm{C}, \mathrm{t}_{\text {minor }}=65.0 \mathrm{~min}($ endo $), \mathrm{t}_{\text {major }}=70.2 \min ($ endo $\left.)\right)$.

(5R,6S)-5-(2-Chlorophenyl)-6-hydroxymethyltetrahydropyrazolo[1,2-a]pyrazol-1-one (endo-3af'): Pale yellow oil; $[\alpha]_{\mathrm{D}}{ }^{24}+1.1^{\circ}(c 0.80, \mathrm{MeOH}$, endo : exo $=88: 12,50 \%$ ee (endo)).; IR (KBr) 3354, 2990, 2943, 2916, 2884, 1653, 1569, 1471, 1422, 1373, 1312, 1272, 1200, 1161, 1139, 1115, 1091, 1053, 1033 $\mathrm{cm}^{-1} ;{ }^{1} \mathrm{H}$ NMR $\left(\mathrm{CDCl}_{3}\right) \delta=2.17(1 \mathrm{H}, \mathrm{brs}), 2.63-2.83(3 \mathrm{H}, \mathrm{m}), 3.00(1 \mathrm{H}, \mathrm{ddd}, J=7.8 .9 .0,11.2 \mathrm{~Hz}), 3.43$ $(1 \mathrm{H}, \mathrm{ddd}, J=7.3,9.3,11.2 \mathrm{~Hz}), 3.54(1 \mathrm{H}, \mathrm{m}), 3.68(1 \mathrm{H}, \mathrm{dd}, J=5.4,11.2 \mathrm{~Hz}), 3.74(1 \mathrm{H}, \mathrm{dd}, J=4.4,11.2$ $\mathrm{Hz}), 3.85(1 \mathrm{H}, \mathrm{dd}, J=6.1,11.2 \mathrm{~Hz}), 4.02(1 \mathrm{H}, \mathrm{d}, J=9.0 \mathrm{~Hz}), 7.20-7.40(3 \mathrm{H}, \mathrm{m}), 7.63-7.71(1 \mathrm{H}, \mathrm{m}) ;{ }^{13} \mathrm{C}$ NMR $\left(\mathrm{CDCl}_{3}\right) \delta=32.5\left(\mathrm{CH}_{2}\right), 44.0\left(\mathrm{CH}_{2}\right), 47.3\left(\mathrm{CH}_{2}\right), 53.4(\mathrm{CH}), 60.9\left(\mathrm{CH}_{2}\right), 66.4(\mathrm{CH}), 127.2(\mathrm{CH})$, $128.9(\mathrm{CH}), 129.0(\mathrm{CH}), 129.3(\mathrm{CH}), 133.9(\mathrm{C}), 135.0(\mathrm{C}), 171.3(\mathrm{C})$; Mass $(\mathrm{EI}) \mathrm{m} / \mathrm{z} 266\left(\mathrm{M}^{+}\right), 151,125$, 84, 77, 56. Anal. Calcd for $\mathrm{C}_{13} \mathrm{H}_{15} \mathrm{ClN}_{2} \mathrm{O}_{2}: \mathrm{C}, 58.54 ; \mathrm{H}, 5.67 ; \mathrm{N}, 10.50 \%$. Found: C, 58.66; H, 5.76; N, $10.30 \%$. The enantiomeric excess was determined by HPLC analysis (Daicel Chiralpak AD-H, hexane : 2-PrOH $=12: 1 \mathrm{v} / \mathrm{v} \%$, detector: UV $254 \mathrm{~nm}$, Flow rate $=1.0 \mathrm{~mL} / \mathrm{min}, 35^{\circ} \mathrm{C}, \mathrm{t}_{\text {minor }}=20.4 \mathrm{~min}$ (endo), $\mathrm{t}_{\text {major }}=35.4 \min ($ endo $\left.)\right)$.

(5R,6S)-6-Hydroxymethyl-5-p-tolyltetrahydropyrazolo[1,2-a]pyrazol-1-one (endo-3ag'): Colorless needles; mp 189-190 ${ }^{\circ} \mathrm{C}$ (benzene); $[\alpha]_{\mathrm{D}}{ }^{27}-6.6^{\circ}$ (c 0.80, MeOH, endo : exo = $99: 1,74 \%$ ee (endo)); IR 
(KBr) 3343, 3026, 2949, 2926, 2889, 2868, 1661, 1518, 1458, 1418, 1381, 1303, 1256, 1215, 1205, 1186 , 1108, 1086, $1024 \mathrm{~cm}^{-1} ;{ }^{1} \mathrm{H}$ NMR $\left(\mathrm{CDCl}_{3}\right) \delta=1.90(1 \mathrm{H}, \mathrm{brs}), 2.36(3 \mathrm{H}, \mathrm{s}), 2.65-2.79(3 \mathrm{H}, \mathrm{m}), 2.93(1 \mathrm{H}, \mathrm{dt}$, $J=11.2,8.4 \mathrm{~Hz}), 3.33(1 \mathrm{H}, \mathrm{d}, J=9.5 \mathrm{~Hz}), 3.43(1 \mathrm{H}, \mathrm{dt}, J=11.2,7.7 \mathrm{~Hz}), 3.53(1 \mathrm{H}, \mathrm{m}), 3.61(1 \mathrm{H}, \mathrm{m})$, $3.70(1 \mathrm{H}, \mathrm{m}), 3.78(1 \mathrm{H}, \mathrm{dd}, J=6.8,9.0 \mathrm{~Hz}), 7.16-7.21(2 \mathrm{H}, \mathrm{m}), 7.26-7.32(2 \mathrm{H}, \mathrm{m}) ;{ }^{13} \mathrm{C} \mathrm{NMR}\left(\mathrm{CDCl}_{3}\right) \delta=$ $21.2\left(\mathrm{CH}_{3}\right), 32.8\left(\mathrm{CH}_{2}\right), 43.2\left(\mathrm{CH}_{2}\right), 47.5\left(\mathrm{CH}_{2}\right), 52.7(\mathrm{CH}), 60.0\left(\mathrm{CH}_{2}\right), 70.9(\mathrm{CH}), 127.5(\mathrm{CH}), 129.2$ (CH), 133.9 (C), 137.7 (C), 170.3 (C); Mass (EI) m/z $246\left(\mathrm{M}^{+}\right)$, 131, 98, 56. Anal. Calcd for $\mathrm{C}_{14} \mathrm{H}_{18} \mathrm{~N}_{2} \mathrm{O}_{2}$ : C, 68.27; H, 7.37; N, 11.37\%. Found: C, 68.35; H, 7.41; N, 11.25\%. The enantiomeric excess was determined by HPLC analysis (Daicel Chiralpak AD-H, hexane : 2-PrOH $=20: 1 \mathrm{v} / \mathrm{v} \%$, detector: UV $254 \mathrm{~nm}$, Flow rate $=0.5 \mathrm{~mL} / \mathrm{min}, 35^{\circ} \mathrm{C}, \mathrm{t}_{\text {minor }}=51.3 \mathrm{~min}($ endo $), \mathrm{t}_{\text {major }}=55.9 \mathrm{~min}($ endo $)$ ).

(5R,6S)-6-Hydroxymethyl-5-(2-naphthyl)tetrahydropyrazolo[1,2-a]pyrazol-1-one (endo-3ai'): Pale yellow prisms; mp 196-197 ${ }^{\circ} \mathrm{C}$ (benzene-MeOH); $[\alpha]_{\mathrm{D}}{ }^{24}-13.7^{\circ}$ (c 0.80, MeOH, endo : exo = $99: 1,82 \%$ ee (endo)).; IR (KBr) 3463, 3402, 3384, 2932, 2888, 2853, 2811, 1671, 1598, 1509, 1472, 1408, 1380, 1349, 1247, 1205, 1127, 1097, 1085, 1064, 1041, $1019 \mathrm{~cm}^{-1} ;{ }^{1} \mathrm{H}$ NMR $\left(\mathrm{CDCl}_{3}\right) \delta=1.96(1 \mathrm{H}$, brs $)$, 2.70-2.83 (2H, m), $2.85(1 \mathrm{H}, \mathrm{m}), 2.99(1 \mathrm{H}, \mathrm{dt}, \mathrm{J}=11.2,8.5 \mathrm{~Hz}), 3.47(1 \mathrm{H}, \mathrm{ddd}, J=7.3,8.5,11.2 \mathrm{~Hz})$, $3.59(1 \mathrm{H}, \mathrm{m}), 3.65(1 \mathrm{H}, \mathrm{m}), 3.75(1 \mathrm{H}, \mathrm{m}), 3.85(1 \mathrm{H}, \mathrm{dd}, J=6.6,11.2 \mathrm{~Hz}), 7.43-7.63$ (3H, m), 7.78-7.92 $(4 \mathrm{H}, \mathrm{m}) ;{ }^{13} \mathrm{C} \mathrm{NMR}\left(\mathrm{CDCl}_{3}\right) \delta=32.8\left(\mathrm{CH}_{2}\right), 43.4\left(\mathrm{CH}_{2}\right), 47.5\left(\mathrm{CH}_{2}\right), 52.8(\mathrm{CH}), 60.2\left(\mathrm{CH}_{2}\right), 71.3(\mathrm{CH})$, $124.9(\mathrm{CH}), 126.1(\mathrm{CH}), 126.2(\mathrm{CH}), 127.3(\mathrm{CH}), 127.5(\mathrm{CH}), 127.6(\mathrm{CH}), 128.5(\mathrm{CH}), 133.0(\mathrm{C}), 133.1$ (C), 134.6 (C), 171.0 (C); Mass (EI) m/z $282\left(\mathrm{M}^{+}\right), 167,78,56$. Anal. Calcd for $\mathrm{C}_{17} \mathrm{H}_{18} \mathrm{~N}_{2} \mathrm{O}_{2}$ : C, 72.32; H, 6.43; N, 9.92\%. Found: C, 72.52; H, 6.20; N, 9.95\%. The enantiomeric excess was determined by HPLC analysis (Daicel Chiralpak OD-H, hexane : 2-PrOH $=20: 1 \mathrm{v} / \mathrm{v} \%$, detector: UV $254 \mathrm{~nm}$, Flow rate $=1.0 \mathrm{~mL} / \mathrm{min}, 35^{\circ} \mathrm{C}, \mathrm{t}_{\text {minor }}=72.9 \min ($ endo $), \mathrm{t}_{\text {major }}=85.7 \mathrm{~min}($ endo $\left.)\right)$.

(5R,6S)-5-Cyclohexyl-6-hydroxymethyltetrahydropyrazolo[1,2-a]pyrazol-1-one

(endo-3aj'):

Colorless oil; $[\alpha]_{\mathrm{D}}{ }^{23}-12.4^{\circ}$ (c $0.60, \mathrm{MeOH}$, endo : exo $=99: 1,31 \%$ ee (endo)); IR (neat) 3374, 3018, 2930, 2856, 2401, 2361, 2339, 1669, 1451, 1426, 1215, $1045 \mathrm{~cm}^{-1} ;{ }^{1} \mathrm{H}$ NMR $\left(\mathrm{CDCl}_{3}\right) \delta=0.87-1.82(11 \mathrm{H}$, m), $1.86(1 \mathrm{H}, \mathrm{brs}), 2.18(1 \mathrm{H}, \mathrm{m}), 2.51(1 \mathrm{H}, \mathrm{m}), 2.65(1 \mathrm{H}, \mathrm{ddd}, J=4.9,9.5,14.4 \mathrm{~Hz}), 2.77(1 \mathrm{H}, \mathrm{m}), 2.94$ $(1 \mathrm{H}, \mathrm{m}), 3.15(1 \mathrm{H}, \mathrm{m}), 3.46(1 \mathrm{H}, \mathrm{dd}, J=7.8,10.7 \mathrm{~Hz}), 3.56-3.70(2 \mathrm{H}, \mathrm{m}), 3.84(1 \mathrm{H}, \mathrm{m}) ;{ }^{13} \mathrm{C} \mathrm{NMR}$ $\left(\mathrm{CDCl}_{3}\right) \delta=26.2\left(\mathrm{CH}_{2}\right), 26.4\left(\mathrm{CH}_{2}\right), 29.79\left(\mathrm{CH}_{2}\right), 29.85\left(\mathrm{CH}_{2}\right), 34.0\left(\mathrm{CH}_{2}\right), 41.2(\mathrm{CH}), 42.5\left(\mathrm{CH}_{2}\right), 46.9$ $(\mathrm{CH}), 52.0\left(\mathrm{CH}_{2}\right), 63.6\left(\mathrm{CH}_{2}\right), 73.4(\mathrm{CH}), 167.6(\mathrm{C})$; Mass $(\mathrm{EI}) \mathrm{m} / \mathrm{z} 238\left(\mathrm{M}^{+}\right), 156,55 . \quad$ Anal. Calcd for $\mathrm{C}_{13} \mathrm{H}_{22} \mathrm{~N}_{2} \mathrm{O}_{2}$ : C, 65.51; H, 9.30; N, 11.75\%. Found: C, 65.27; H, 9.52; N, 11.71\%. The enantiomeric excess was determined by HPLC analysis (Daicel Chiralpak OD-H, hexane : 2-PrOH $=20: 1 \mathrm{v} / \mathrm{v} \%$, detector: UV $254 \mathrm{~nm}$, Flow rate $=1.0 \mathrm{~mL} / \mathrm{min}, 35^{\circ} \mathrm{C}, \mathrm{t}_{\text {major }}=22.2 \mathrm{~min}($ endo $), \mathrm{t}_{\text {minor }}=27.6 \min ($ endo $)$ ). 
(5R,6S)-6-hydroxymethyl-5-Isobutyltetrahydropyrazolo[1,2-a]pyrazol-1-one (endo-3ak'): Colorless oil; $[\alpha]_{\mathrm{D}}{ }^{23}-18.4^{\circ}$ (c 0.80, MeOH, endo : exo = $83: 17,32 \%$ ee (endo)); IR (KBr) 3282, 3000, 2954, 2913 , 2905, 2866, 1671, 1470, 1426, 1377, 1366, 1328, 1319, 1253, 1226, 1191, 1165, 1150, 1109, $1091 \mathrm{~cm}^{-1}$;

${ }^{1} \mathrm{H}$ NMR $\left(\mathrm{CDCl}_{3}\right) \delta=0.94(3 \mathrm{H}, \mathrm{d}, J=6.6 \mathrm{~Hz}), 0.95(3 \mathrm{H}, \mathrm{d}, J=6.6 \mathrm{~Hz}), 1.33-1.58(2 \mathrm{H}, \mathrm{m}), 1.61-1.83(2 \mathrm{H}$, m), $2.43(1 \mathrm{H}, \mathrm{m}), 2.50(1 \mathrm{H}, \mathrm{m}), 2.66(1 \mathrm{H}, \mathrm{ddd}, J=5.1,9.3,14.4 \mathrm{~Hz}), 2.77(1 \mathrm{H}, \mathrm{m}), 2.99(1 \mathrm{H}, \mathrm{q}, J=9.3$ $\mathrm{Hz}), 3.32(1 \mathrm{H}, \mathrm{m}), 3.54-3.65(2 \mathrm{H}, \mathrm{m}), 3.66-3.77(2 \mathrm{H}, \mathrm{m}) ;{ }^{13} \mathrm{C} \mathrm{NMR}\left(\mathrm{CDCl}_{3}\right) \delta=22.7\left(\mathrm{CH}_{3}\right), 23.4\left(\mathrm{CH}_{3}\right)$, $25.4(\mathrm{CH}), 33.9\left(\mathrm{CH}_{2}\right), 34.0\left(\mathrm{CH}_{2}\right), 42.5\left(\mathrm{CH}_{2}\right), 42.5\left(\mathrm{CH}_{2}\right), 50.4(\mathrm{CH}), 62.2\left(\mathrm{CH}_{2}\right), 65.4(\mathrm{CH}), 167.9(\mathrm{C})$.; Mass (EI) m/z $212\left(\mathrm{M}^{+}\right), 156,125,81,55$; HRMS (EI) Calcd for $\mathrm{C}_{11} \mathrm{H}_{20} \mathrm{~N}_{2} \mathrm{O}_{2}$ : $\left(\mathrm{M}^{+}\right), 212.1215$. Found: 212.1551. Anal. Calcd for $\mathrm{C}_{11} \mathrm{H}_{20} \mathrm{~N}_{2} \mathrm{O}_{2}: \mathrm{C}, 62.23 ; \mathrm{H}, 9.50 ; \mathrm{N}, 13.20 \%$. Found: C, 61.92; H, 9.90; N, 13.11\%. The enantiomeric excess was determined by HPLC analysis (Daicel Chiralpak AD-H, hexane : $2-\mathrm{PrOH}=20: 1 \mathrm{v} / \mathrm{v} \%$, detector: UV $254 \mathrm{~nm}$, Flow rate $=1.0 \mathrm{~mL} / \mathrm{min}, 35^{\circ} \mathrm{C}, \mathrm{t}_{\text {major }}=17.3 \mathrm{~min}$ (endo), $\mathrm{t}_{\text {minor }}=21.2 \min ($ endo $), \mathrm{t}_{\text {mimor }}=36.2 \min ($ exo $), \mathrm{t}_{\text {major }}=41.0 \min ($ exo $\left.)\right)$.

\section{ACKNOWLEDGEMENTS}

This work was supported in part by a Grant-in-Aid for Scientific Research (nos. 17550097, 20550094, and 20200052) from the Ministry of Education, Science and Culture, Japan.

\section{REFERENCES AND NOTES}

$\dagger$ Shinshu University

* Rigaku Corporation

1. (a) R. Huisgen, H.-J. Hansen, H. Heimgartner, P. Caramella, P. Grünanger, M. Regitz, H. Heydt, W. Lwowski, J. W. Lown, and R. Grashey, '1,3-Dipolar Cycloaddition Chemistry; General Heterocyclic Chemistry Series,' Vol. 1, ed. by A. Padwa, John Wiley and Sons, New York, 1984. (b) K. T. Potts, J. J. Tufariello, R. C. Storr, R. L. Kuczkowski, A. Padwa, K. N. Houk, K. Yamaguchi, G. Bianchi, R. Gandolfi, J. N. Crabb, and R. C. Storr, '1,3-Dipolar Cycloaddition Chemistry; General Heterocyclic Chemistry Series,' Vol. 2, ed. by A. Padwa, John Wiley and Sons, New York, 1984.

2. For recent reviews, see: (a) L. M. Stanley and M. P. Sibi, Chem. Rev., 2008, 108, 2887. (b) H. Pellissier, Tetrahedron, 2007, 63, 3235. (c) J. M. Martin, R. C. F. Jones, S. E. Denmark, J. J. Cottell, L. M. Harwood, R. J. Vickers, M. C. McMills, D. Wright, G. Mloston, H. Heimgartner, V. Jäger, P. A. Colinas, J. T. Sharp, G. Maas, C.-K. Sha, A. K. Mohanakrishnan, G. W. Gribble, S. Kanemasa, K. 
G. Gothelf, and K. A. Jørgensen, 'Synthetic Applications of 1,3-Dipolar Cycloaddition Chemistry toward Heterocycles and Natural Products,' ed. by A. Padwa, and W. H. Pearson, John Wiley and Sons, Hoboken, NJ, 2003, pp. 1-940. For representative examples of reactions using organocatalysts, see: (d) W. S. Jen, J. J. M. Wiener, and D. W. C. MacMillan, J. Am. Chem. Soc., 2000, 122, 9874. (e) S. Karlsson and H.-E. Högberg, Eur. J. Org. Chem., 2003, 2782. (f) S. S. Chow, M. Nevalainen, C. A. Evans, and C.W. Johannes, Tetrahedron Lett., 2007, 48, 277. (g) J. L. Vicario, S. Reboredo, D. Badia, and L. Carrillo, Angew. Chem. Int. Ed., 2007, 46, 5168. (h) M.-X. Xue, X.-M. Zang, and L.-Z. Gong, Synlett, 2008, 691. (i) W. Du, Y.-K. Liu, and Y.-C. Chen, Synlett, 2008, 2997. (j) L. Weselinski, P. Stepniak, and J. Jurczak, Synlett, 2009, 2261.

3. H. Suga, T. Nakajima, K. Itoh, and A. Kakehi, Org. Lett., 2005, 7, 1431.

4. H. Suga, A. Funyu, and A. Kakehi, Org. Lett., 2007, 9, 97.

5. H. Suga, Y. Adachi, K. Fujimoto, Y. Furihata, T. Tsuchida, A. Kakehi, and T. Baba, J. Org. Chem., 2009, 74, 1099.

6. (a) H. Suga, D. Ishimoto, S. Higuchi, M. Ohtsuka, T. Arikawa, T. Tsuchida, A. Kakehi, and T. Baba, Org. Lett., 2007, 9, 4359. (b) H. Suga, S. Higuchi, M. Ohtsuka, D. Ishimoto, T. Arikawa, Y. Hashimoto, S. Misawa, T. Tsuchida, A. Kakehi, and T. Baba, Tetrahedron, 2010, 66, 3070.

7. M. P. Sibi, D. Rane, L. M. Stanley, and T. Soeta, Org. Lett., 2008, 10, 2971.

8. More recently, asymmetric 1,3-dipolar cycloadditions between $C, N$-cyclic azomethine imines and $\alpha, \beta$-unsaturated aldehydes catalyzed by a titanium-BINOLate complex have been reported: $\mathrm{T}$. Hashimoto, Y. Maeda, M. Omote, H. Nakatsu, and K. Maruoka, J. Am. Chem. Soc., 2010, 132, 4076.

9. W. Chen, X.-H. Yuan, R. Li, W. Du, Y. Wu, L.-S. Ding, and Y.-C. Chen, Adv. Synth. Catal., 2006, 348, 1818.

10. W. Chen, W. Du, Y.-Z. Duan, Y. Wu, S.-Y. Yang, and Y.-C. Chen, Angew. Chem. Int. Ed., 2007, 46, 7667.

11. The reactions in the other solvent systems examined in the presence of L-proline (30 mol\%) at room temperature did not also show satisfactory results. $\mathrm{CH}_{2} \mathrm{Cl}_{2} / \mathrm{MeOH}$ 94:6 (v/v): 162 h, 39\% yield, endo:exo = 98:2, -3\% ee (endo); EtOH: 72 h, 34\% yield, endo:exo =91:9, -8\% ee (endo); DMF: 186 h, No reaction; $\mathrm{CHCl}_{3} / \mathrm{H}_{2} \mathrm{O}$ 99:1 (v/v): 324 h, No reaction.

12. The reaction without L-proline was sluggish but slowly proceeded at room temperature for $231 \mathrm{~h}$ in

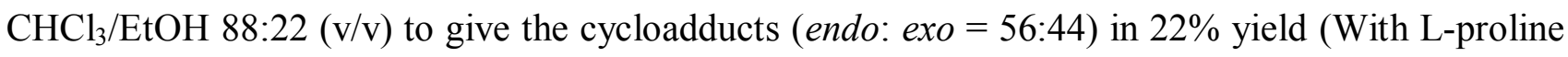
(30 mol\%) under same conditions: 53 h, 63\% yield, endo: exo $=98: 2,66 \%$ ee (endo)).

13. H. Ohtake, Y. Imada, and S. Murahashi, Bull. Chem. Soc. Jpn., 1999, 72, 2737. 
14. K. Li, Z. Zhou, L. Wang, Q. Chen, G. Zhao, Q. Zhou, and C. Tang, Tetrahedron: Asymmetry, 2003, 14, 95 .

15. M. Marigo, T. C. Wabnitz, D. Fielenbach, and K. A. Jørgensen, Angew Chem. Int. Ed., 2005, 44, 794.

16. (a) R. Shintani and G. C. Fu, J. Am. Chem. Soc., 2003, 125, 10778. (b) A. Suárez, W. Downey, and G. C. Fu, J. Am. Chem. Soc., 2005, 127, 11244. 